\title{
CORRELATION ANALYSIS OF INDICATORS OF REGIONAL COMPETITIVENESS: THE CASE OF THE REPUBLIC OF SERBIA
}

\author{
Darko B. Vukovic* \\ Geographical Institute "Jovan Cvijic" of the Serbian Academy of Sciences and Arts
}

The identification and analysis of the indicators of regional competitiveness is the most important phase of the process of measuring competitiveness. However, prior to the measurements, it is necessary to determine whether there is a high correlation between the selected indicators or not. The aim of this paper is to determine whether there is a high correlation between the most important indicators of regional competitiveness or not. The subject of this paper are the indicators of competitiveness in Serbia's regions, whose values are measured in the 2011-2013 period. For the indicators unrelated to each other or those having no logical mutual influence, no correlation was revealed. On the basis of these results, it turns out that there is a high correlation between the GDP of the region, the number of companies in the region, the number of employees, the extent of the cluster, investments in innovation and confidence in business institutions. The Pearson correlation coefficient statistical method has been used in the estimation. These data, whose measure cannot be achieved through quantitative measurement, have been obtained in the survey.

Keywords: regional competitiveness, indicators of regional competitiveness, correlation analysis of the indicators of regional competitiveness

\section{JEL Classification: R10, R58, 018}

\section{INTRODUCTION}

The theory of competition is as old as economics itself as a scientific discipline. There is no representative of the school of economics who has not dealt with the issue of competition (either in terms of the international economy, or productivity, or pricing,

\footnotetext{
* Correspondence to: D.B. Vuković, Geographical Institute „Jovan Cvijić" of the Serbian Academy of Sciences and Arts, Djure Jaksica 9/3, 11000 Belgrade, Serbia; e-mail: d.vukovic@gi.sanu.ac.rs
}

or consumer behavior etc.). Therefore, it can be said that the economy in the modern sense is a struggle for a market, taking into account the economic laws, principles and any other categories studied in this science. In particular, we can talk about the macro economy, human resources, finance, international relations, productivity, customer relations etc., where each of these branches or categories can differently be observed and analyzed, but where the combined effects more or less boil down to a "certain characteristic" or an output that will allow a better position in relation to another company, city, region or country. 
The term of competitiveness is widespread in the economic literature. Many economists have been explaining this term for decades, one can even say for centuries, with the key questions: How to understand this issue and what is the best possible way to do so? Which one is most important for the growth of economic wealth and the most effective for its distribution? Different authors define it differently at the level of companies, the industry, the region or the city; because of the complexity of the term, however, there is no generally accepted definition. The wider term of competitiveness refers to the propensity and skill of competition, the ability to win and retain a market position, and increase the market share and profitability. Hence, the term of competitiveness means the success of a business. Due to the complexity of the concept, a variety of factors and the nature of the competitive process, the term of competitiveness is difficult to explain and often confusing, especially at the regional level (Snieška \& Bruneckienè, 2009).

The level which competitiveness is defined at is the most important aspect of this concept (Annoni \& Kozovski 2010; Kitson et al, 2004). The indicators of regional competitiveness provide important information about the "strength" of the region to achieve an adequate economic performance, provide appropriate social care and quality infrastructure, generate innovation, develop human capital, possess geographical and natural potentials, have adequate institutions and promote culture and develop tourism. Competitiveness can be possible to measure by identifying, selecting and analyzing these indicators.

The subject of this paper are the indicators of competitiveness observed in the regions of Šumadija and Western Serbia, in Belgrade, Vojvodina, Eastern and Southern Serbia, as well as in the region of Kosovo and Metohija (for which data are not or are hardly available) in the period 2011-2013. The objective of this paper is to determine the correlation of the observed indicators. The paper does not deal with the issue of the indicator values and their comparison with the same competitors' indicators, but rather with their correlation dependence. The measurement of the indicators and their analysis have a full scientific and practical significance only in the case of the highly-correlated indicators of competitiveness. Such a correlation must exist for related or associated indicators, rather than for all of the groups of indicators. For example, a high degree of correlation is expected between the group of economic indicators (high employment correlated with the GDP growth) or institutional indicators (the quality of the business environment is positively correlated with an increase in the number of companies), but these indicators are not expected to be positively correlated with the indicators of a natural environment or social indicators (a high correlation between the indicators of the number of housings and the amount of waste water). Based on the defined research objectives, this paper starts from the following hypothesis:

$\mathrm{H}$ : There is a correlation of the indicators of regional competitiveness.

The paper is structured in the following manner: after the introductory section, where the problems of the research and the hypothesis are defined, the theoretical background is presented, with the reference to the international literature. Further, the research methodology will be discussed in a separate section. Finally, the results of the researched problems and the conclusion are presented. The data representing the values of the indicators have been obtained in the following manner: a) the quantitative data have been obtained from the Statistical Office of the Republic of Serbia, the National Bank of Serbia and the Serbian Business Registers Agency; $b$ ) the qualitative data have been obtained through surveys.

\section{THEORETICAL APPROACH}

The economy of the entire country and the world economy directly depend on the the economic and social sustainability of regions and their ability to be competitive. If the applied regional competitiveness strategy is not effective and also when the factors of competitiveness are not being fully utilized, then regions (or a region) will lose their competitive position and there will be a negative impact on national competitiveness (Vuković, 2013). In order to avoid a possible risk of a loss of a competitive position, it is necessary that regional competitiveness be measured. 
Therefore, the measurement of competitiveness is the most important stage in strategic planning in order to improve regional and national competitiveness. Despite the growing interest of the scientific literature in the problem of regional competitiveness (Porter, 1990; Rugman et al, 1998; Cho \& Moon, 2000; Reiljan et al, 2000; The European Commission, 1999, 2001; Gardiner et al, 2004; Martin, 2005; Lengyel, 2004; Houvari et al, 2001; OECD 1997; Boschma, 2004; Cho, 2005; Vuković et al, 2012), the theoretical explanations of this concept are amongst the most difficult and complicated ones in the economy. The competitiveness of a region can be expressed in various ways: by analyzing one or more factors of competitiveness, by using theoretical models of competitiveness, by the creating of a composite index, by combining several methods etc. In measuring regional competitiveness, a number of authors (Lengyel, 2004; Kitson et al, 2004; de Vet et al, 2004; Huggins, 2003) showed that competitiveness cannot only be based on the measurement of economic and social factors and their indicators, but a multifactorial complex measurement must be performed (Freudenberg, 2003; Wignaraja et al, 2004; IMD 2004; Giovannini et al, 2005; Saisana et al, 2005; Huggins, 2003; Snieška \& Bruneckienè 2009; Vuković 2013). Thus, the identification of the indicators of regional competitiveness, which are an integral part of the factors of regional competitiveness, stands for the most important aspect of the analysis of regional competitiveness.

How does the international literature define the term of competitiveness? The macroeconomic concept of competitiveness is difficult to define and includes many controversies (The European Commission, 2003). In spite of the fact that the improvement of economic and regional competitiveness is often presented as the main goal of an economic policy, a lack of generally accepted definitions is an important argument stating that: It is dangerous to link the central policy to competitiveness-related issues. P. Krugman (1994) goes further, arguing that the concept of national competitiveness is meaningless, referring to it as a "dangerous obsession" for the following three key reasons:

- It is misleading and inaccurate to make analogies between nations (the economy) and the company.
For example, unsuccessful firms will be driven out of the market, but there is no such "bottom line" equivalent for a nation.

- When companies compete for a market share, then one company's success is achieved to the detriment of other less successful ones (which suffer higher costs). This rule cannot be applied to a national economy, because one economy's or one region's success rather improves than distorts international trade (other countries). This effect is referred to as the "zero sums" game.

- If competitiveness makes a sense, it is simply another way of expressing productivity. The growth of living standards in a country essentially depends on the rate of productivity growth.

According to the definition provided by The World Economic Forum, competitiveness is a set of institutions, policies and factors determining the level of the productivity of a country (Schwab \& Porter, 2007). At the micro level, competitiveness is the ability of companies to compete, grow and be profitable (Martin et al, 2006; Powell, 2001), or the ability of a company to produce and sell products and services at a lower price compared to its competitors, or with other non-price factors more attractive than a competing bid (IMD, 2000). In other words, competitiveness is defined as a company's ability to consistently and profitably produce an output satisfying the requirements of an open market in terms of price, quality etc. Most often, the micro level of competitiveness refers to a company's performance (Domanović, 2013). Even though these are two different aspects, the two views of competitiveness, there is a strong and direct connection between the macro and micro levels (Schwab \& Porter, 2007). Many authors, including P. Krugman (1994, 1996), considered that the definition of competitiveness refers to productivity, which measures the value of goods and services per unit of factor produced in a particular territory. According to these authors, the aims of competitiveness are related to achieving higher productivity, which affects the growth of the living standards.

Between the macro and micro levels of competition, the concept of regional competitiveness is defined. According to the original meaning covered in the 
Global Competitiveness Index (the World Economic Forum), it may implicitly be understood that regional competitiveness is the level of the quality of life in one region. Also, regional competitiveness can be expressed as the ability to attract production factors. The term of regional competitiveness can neither be expressed as macro- nor microeconomic determinants because the regions are not simply the scaled versions of a particular nation or just an aggregate expression of companies in a regional space (Ward, 2005; Gardiner et $a l, 2004)$. Therefore, competitiveness at a regional level does not only result from macroeconomic stability or entrepreneurship at a micro level, but from new forms of competitiveness inclusive of a regional component (Annoni \& Kozovski, 2010). According to J. MeyerStamer (2008), the competitiveness of a territory is the ability of localities or regions to produce a high and rising income as well as to improve the living standards of the people living in that particular territory. This definition focuses on a close relationship between regional competitiveness and regional prosperity, characterizing not only the terms of "output relations" (such as productivity) but also overall economic performances (Bristow, 2005). R. Huggins (2003) points out that local and regional competitiveness occurs only when sustainable growth is achieved in the cost of labor, which affects the growth of the living standards.

Defining the term of regional competitiveness is a very difficult task to do, because there is still no generally accepted definition (Vukovic \& Wei, 2010). One of the most commonly used definitions, or perhaps more appropriately "the least disputed one", is the definition provided by the European Commission (1999), where the competitiveness of a region is defined as its ability to produce goods and services that meet international market criteria, simultaneously maintaining a high and sustainable level of income. Generally speaking, the competitiveness of a region is its ability to produce, while at the same time being exposed to external competition, with relatively high levels of income and employment.

According to M. Porter (1990), if a government creates such a business environment where favorable conditions for business exist and where the government is doing the best it can to support companies performing their operations on the local and global markets, these conditions represent the nation's competitive advantage. According to the same author, this argument can also be implemented on a regional level. P. Krugman does not agree with M. Porter: "The idea that the welfare and economic performances of a state depend on its success on the global market is a hypothesis and does not necessarily imply truth; moreover, the practical and empirical views proved this hypothesis to be completely wrong" $(1994,30)$. The same author believes that the world leading nations are not competing with one another and that there is no "significant degree of competition" among them. Many authors (Krugman, 1994, 3134; Kern, 2005, 173; Ručinska \& Ručinsky, 2007, 904) consider that competition between companies and regions cannot be compared. Companies can enter or exit from a market depending on their success, but regions cannot leave their territories regardless of their success. On the basis of this, it is possible to emphasize the main difference between the competitiveness of a company and a region: Companies fight with each other and can improve their position in the market by ousting another company or worsen the position of another company (the Pareto Optimum), while regions can improve their positions simultaneously without jeopardizing the positions of other regions.

The competitiveness of a region can be seen in two ways: First, through specific drivers providing a region with an opportunity to use its competitive advantage and compete with other regions; and second, through the results (incomes) achieved using specific factors and indicators. Bearing in mind the aforesaid, some papers analyze competitiveness based on a cumulative result created by the existence of different factors and the indicators a region possesses, while some analyze regional drivers (Rucinski \& Ručinský, 2007). These drivers of regional competitiveness, or in other words these inherited conditions of competition, represent regional facilities that make such a region specific: infrastructure facilities, security, the technical characteristics of the region, natural resources, the level and scope of services, the number of enterprises, the quality and availability of labor, the number and quality of educational institutions, the quality of the public administration, the historical frame of the region. When competition is based on a particular 
outcome, then it comes down to regional economic development indicators such as the regional GDP per capita, the unemployment rate, the average wage, the foreign direct investment, the innovation (Joksimović, 2008) etc. The drivers of competitiveness can be intangible indicators, such as confidence. According to V. Leković (2012), investments are not possible without confidence. Transaction costs increase, which accordingly creates serious obstacles in functioning and development. Informal institutions are also used as an indicator: the quality of the business environment, the extent of clusters and other indicators listed as intangible.

\section{RESEARCH METHODOLOGY}

Numerous data are included using the method of a statistical analysis, required for determining the value of an indicator. These data can include: the education structure of the population, the physical infrastructure, patents, scientific projects in the country and abroad, the gross domestic product, business entities, initiated and completed bankruptcy proceedings, the productivity of workers, employment and unemployment rates, investment in capital assets, gross incomes, consumption, tourism facilities and so on. According to the result lists of the Statistical Office of the Republic of Serbia, the Republic Geodetic Authority and other relevant institutions of the Republic of Serbia, a considerable amount of the research data have been collected. Those data not included in these institutions' lists were generated from the sample created by the survey. The data have only been collected by means of the techniques, instruments and methods of a statistical analysis.
Both the quantitative and the qualitative data have been collected by means of this method. The general scientific statistical method is faced with all kinds of data that can be expressed in numerical indicators, i.e. all of those which can quantitatively be expressed. At the same time, for each quantified statement is related to the measurement, so this method almost identified with the measurements. The collected data show certain properties (or the quality) of a certain amount (the quantity) in a certain time (the chronological order) and in an area (geographically).

The correlation coefficient is a frequently used statistical method showing a correlation between the values of variables. A correlation analysis does not apply to the properties detected in relationships but only to the existence and frequency of those relationships. This analysis is one of the most complex ones. The value of the correlation is determined by measuring a correlation coefficient, which is a numeric value indicating a degree of correlation between two variables. This value ranges from -1 to +1 . In this paper, the correlation coefficient was calculated using the SPSS as Pearson's and Spearman's correlation coefficients. Spearman's rank-correlation coefficient is a nonparametric equivalent of Pearson's coefficient of a linear correlation. The difference between these two ratios lies in the fact that the calculation is not performed by the numerical values of the dependent and independent variable phenomena, but rather in their relative ratios, i.e. ranks.

Spearman's correlation coefficient is calculated as:

$\sigma=1-\left[6 \sum \mathrm{d} 2 / \mathrm{n}(\mathrm{n} 2-1)\right]$

where: $\sigma$ - Spearman's correlation coefficient, $\mathrm{d}$ - the difference between the ranks of $\mathrm{x}$ and $\mathrm{y}, \mathrm{n}$ - the number

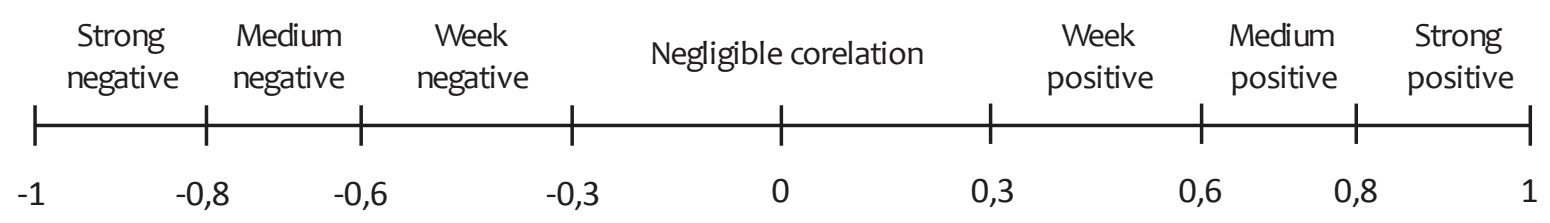

Figure 1 The scale of correlation 
of the pairs of rank variables $x$ and $y$. The correlation coefficient takes a value between -1 and 1 .

The difference between Pearson's simple linear correlation coefficient and Spearman's rank correlation coefficient is in that the latter can be calculated from data when the measurement is performed on an ordinal scale. Spearman's coefficient can replace Pearson's coefficient if an interval data could be converted into ordinal one, i.e. if they are ranked by their size. Conversely, if a data has been presented in an ordinal scale, only Spearman's coefficient can be applied. The statistical strength of Pearson's coefficient is significantly higher in comparison with Spearman's and if the data are supplied in an interval, priority is given to Pearson's. Due to the easiness of calculation, Spearman's coefficient is only used as a test. All the data related to the indicators in this paper are calculated by Pearson's coefficient, due to its statistical power. The general rule in the correlation is next: When the value of a simple linear correlation coefficient is closer to one, the interdependency among the observed phenomena is stronger.

The correlation analysis has a goal to show a correlation between the variables, i.e. whether there is dependence between indicators of regional competitiveness or not. This analysis is not carried out to determine the dependence of all indicators, but only the one of those indicators (i.e. couples of indicators) for which there is some meaning or significance of measurements. For example, it would be absurd to measure a correlation of the pairs of indicators of the total water supply and the number of libraries or the quality of the railways and the number of cinemas. Therefore, only logicallyinterrelated indicators are measured in this analysis.

During the identification of the factors and the indicators of regional competitiveness, it was found that some indicators could not (statistically) be documented, but have rather been necessary to create the survey, such as interviewing techniques. This perceptual technique has a role to collect data that cannot quantitatively be collected or those very difficult to measure. A written survey has been used for the purpose of the analysis in this paper. The survey involves a written communication between the interviewer and the respondent in relatively non-standardized forms. An informal or nonstandardized form only applies to the modalities of the answers enrolled at their discretion and where a modality is only given in the frame. The structure of the questions, however, is more formalized because it is related to a number of questions (with clear instructions and a request for the accurate modalities of the responses). Compared to the subtypes of the survey, this survey was conducted by electronic mail. The sample which the survey was conducted for is effective and representative. It consists of a group of experts competent for the research. These experts include: government experts, experts from universities and research institutes and experts from companies (which have a regional influence or operate regionally). Given the fact that the sample was carefully chosen, the subjectivity of the responses and the possibility of errors were kept to a minimum. In this way, important data for the indicators of the quality of the business environment and informal institutions, which can only perceptually be measured, have been obtained.

\section{RESEARCH RESULTS}

This paper analyzes the correlation of the 37 indicators of regional competitiveness. The number of the indicators determining the factors of regional competitiveness is larger and includes the following indicators: the geographic location, agricultural and industrial facilities and other indicators influencing the competitiveness of a region. However, due to the comparability of the data and the complexity of the analysis of a number of indicators, this study is limited to a group of 37 selected indicators (presented in the tables below). The correlation of the indicators is analyzed by using thee SPSS, where the quantitative statistical and the qualitative data were previously grouped and processed. The following tables only account for the values of the obtained correlation coefficients.

The Gross Domestic Product (GDP) of the region has nearly a perfect positive correlation with the indicator of the number of companies in the region (close to 1). Pearson's coefficient of 0.998 tells us that an increase in the number of companies always affects an increase 
in the GDP of the region (Table 1). The situation is similar with the indicator of the number of employees in the region. Even though this indicator is slightly less correlated with the indicator of the GDP, the correlation is positive and strong. This means that the growth of employment in a region has a large impact on its GDP growth rate. Investments in capital assets have a medium positive correlation. The growth of investment certainly affects the GDP growth rate, but not to the extent which they have companies and number of employees. The indicator related to the number of entrepreneurs in the region is weakly correlated with the indicator of the GDP, which means that it influences its growth to a lesser extent. The correlation analysis of these indicators has showed logical and expected results.

Regarding the indicator of employment (Table 2), there is a positive correlation with the indicator of the budgetary expenditures in education. This link shows that greater government investments in education affect the growth of employment. Investments in education have a slightly less positive correlation (medium-positive), but they certainly affect the growth of employment. These two indicators have the expected correlation between the number of employees in the region. However, there is a surprising connection between the indicators of the working-age population and the population with higher education with the employment indicator. Not only is the correlation between the two negligible but it is also negative. Pearson's coefficient shows that these indicators in our region have almost no impact or negligibly influence the growth of employment (when their values fall).

Table 3 below accounts for the fact that the correlation analysis of the indicators of the business environment has yielded the expected results. The strong positive correlation between the quality of the state services, the attractiveness of the business environment and the extent of the clusters is indicative of the great importance of these indicators and their perfectlypositive correlation dependence. The Pearson coefficient is even maximally positive (1) when comparing the interdependence of the indicators of the extent of the clusters and the attractiveness of the business environment. When these indicators are concerned, the connectivity of air transportation with foreign countries and the independence of the judiciary have a strong-positive dependence, but at a slightly

Table 1 The correlation of the GDP in the region with the basic economic indicators, according to Pearson's correlation coefficient

\begin{tabular}{ccccc}
\hline & $\begin{array}{l}\text { The number of com- } \\
\text { panies in the region }\end{array}$ & $\begin{array}{c}\text { The number of em- } \\
\text { ployees in the region }\end{array}$ & $\begin{array}{c}\text { Investments in } \\
\text { capital assets }\end{array}$ & $\begin{array}{c}\text { The number of entre- } \\
\text { preneurs in the region }\end{array}$ \\
\cline { 2 - 5 } Regional GDP & 0,998 & 0,981 & 0,726 & 0,391 \\
\hline
\end{tabular}

Source: Author's calculations, according to the Statistical Office of the Republic of Serbia (2012a) and the Serbian Business Registers Agency (2012)

Table 2 The correlation of the employment indicators and the basic indicators of human capital in the regions, according to Pearson's correlation coefficient

\begin{tabular}{lcccc}
\hline & $\begin{array}{c}\text { Working-age popula- } \\
\text { tion (16-64) }\end{array}$ & $\begin{array}{c}\text { Population with } \\
\text { higher education }\end{array}$ & $\begin{array}{c}\text { Budgetary expendi- } \\
\text { tures in education }\end{array}$ & $\begin{array}{c}\text { Investments in } \\
\text { education }\end{array}$ \\
\cline { 2 - 5 } $\begin{array}{l}\text { The number of em- } \\
\text { ployees in the region }\end{array}$ & $-0,177$ & $-0,197$ & 0,988 & 0,631 \\
\hline
\end{tabular}


Table 3 The correlation of the key indicators of the business environment, according to Pearson's correlation coefficien

\begin{tabular}{|c|c|c|c|c|c|c|}
\hline & $\begin{array}{l}\text { The extent } \\
\text { of the clus- } \\
\text { ters }\end{array}$ & $\begin{array}{l}\text { Connectivity of } \\
\text { air transporta- } \\
\text { tion with foreign } \\
\text { countries }\end{array}$ & $\begin{array}{c}\text { The share of the gray } \\
\text { economy in business } \\
\text { activities }\end{array}$ & $\begin{array}{l}\text { The indepen- } \\
\text { dence of the } \\
\text { judiciary }\end{array}$ & $\begin{array}{c}\text { The attractiveness } \\
\text { of the business } \\
\text { environment }\end{array}$ & $\begin{array}{l}\text { The safety } \\
\text { of property } \\
\text { rights }\end{array}$ \\
\hline $\begin{array}{l}\text { The quality } \\
\text { of the state } \\
\text { services }\end{array}$ & 0,994 & 0,827 & 0,527 & 0,801 & 0,996 & 0,608 \\
\hline & $\begin{array}{l}\text { The extent } \\
\text { of the clus- } \\
\text { ters }\end{array}$ & $\begin{array}{l}\text { Connectivity of } \\
\text { air transporta- } \\
\text { tion with foreign } \\
\text { countries }\end{array}$ & $\begin{array}{c}\text { The share of the gray } \\
\text { economy in business } \\
\text { activities }\end{array}$ & $\begin{array}{l}\text { The indepen- } \\
\text { dence of the } \\
\text { judiciary }\end{array}$ & $\begin{array}{l}\text { The safety of } \\
\text { property rights }\end{array}$ & $\begin{array}{l}\text { The quality } \\
\text { of the state } \\
\text { services }\end{array}$ \\
\hline $\begin{array}{l}\text { The attrac- } \\
\text { tiveness of } \\
\text { the business } \\
\text { environment }\end{array}$ & 1,000 & 0,862 & 0,581 & 0,772 & 0,602 & 0,996 \\
\hline
\end{tabular}

Source: Vuković, 2012

lesser degree. The safety of property rights and the share of the gray economy in business activities have a medium-positive and a weak-positive correlation with the indicators of the business environment, respectively.

Innovations have a strong impact on the GDP growth rate in the region and on the creation and growth of the clusters (Table 4). The strong-positive correlation between the indicators of innovations just confirms this relationship. Almost all indicators of innovations showed highly positive values of Pearson's coefficient (above 0.9), except for the indicator the number of registered patents and published scientific research papers, which has a weak-positive correlation. Confidence has a strong-positive correlation with the GDP. The highly positive coefficient indicates that the greater one's confidence in business institutions, the higher the GDP is.

Tourism is weakly correlated with the indicators of the infrastructure (Table 5). The small-positive values

Table 4 The correlation of the key indicators of innovation and informal institutions, according to Pearson's correlation coefficient

\begin{tabular}{|c|c|c|c|c|c|c|}
\hline & $\begin{array}{l}\text { The number of orga- } \\
\text { nizations engaged in } \\
\text { R\&D }\end{array}$ & $\begin{array}{l}\text { Expendi- } \\
\text { tures for } \\
\quad R \& D\end{array}$ & $\begin{array}{l}\text { Investments } \\
\text { in Innovation }\end{array}$ & $\begin{array}{l}\text { The number } \\
\text { of registered } \\
\text { patents }\end{array}$ & $\begin{array}{l}\text { The extent } \\
\text { of clusters }\end{array}$ & $\begin{array}{l}\text { Confidence } \\
\text { in business } \\
\text { institutions }\end{array}$ \\
\hline \multirow[t]{2}{*}{ Regional GDP } & 0,934 & 0,967 & 0,932 & 0,452 & 0,999 & 0,947 \\
\hline & $\begin{array}{l}\text { The number of em- } \\
\text { ployees in } R \& D\end{array}$ & $\begin{array}{l}\text { Expendi- } \\
\text { tures for } \\
\quad R \& D\end{array}$ & $\begin{array}{l}\text { The total } \\
\text { number of } \\
\text { scientific } \\
\text { papers }\end{array}$ & $\begin{array}{l}\text { Published sci- } \\
\text { entific research } \\
\text { papers }\end{array}$ & $\begin{array}{l}\text { Invest- } \\
\text { ments in } \\
\text { Innovation }\end{array}$ & $\begin{array}{c}\text { The number } \\
\text { of registered } \\
\text { patents }\end{array}$ \\
\hline $\begin{array}{l}\text { The extent of the } \\
\text { clusters }\end{array}$ & 0,961 & 0,957 & 0,947 & 0,580 & 0,918 & 0,482 \\
\hline
\end{tabular}


indicate a negligible impact. The total of water supply is medium-positively correlated with tourism, but has a weak-negative correlation compared with corruption. Regarding the social factors, the largest positive correlation is between the indicators of investments in water supply and the amount of hazardous waste in the region. The amount of hazardous waste has a low- or highly negative correlation with the other indicators, which is expected.

\section{CONCLUSION}

Through the researches they have carried out, many authors have confirmed this view (Porter, 1990, 1998; Storper, 2005; Cooke, 2004; Meyer-Stamer, 2008). Regardless of whether competitiveness is considered as productivity (Krugman, 1990, 9) and/ or as an increase in the living standards (Porter, 1992), competition is based on cumulative results derived from the existence of factors typical of a particular region. Those regions that have developed faster and in which there are a large number of different factors also have a better competitive position. In other words, the higher utilization or availability of competitiveness indicators provides an opportunity for a region to build up an advantage over the factors of regional competitiveness, which are just composed of these indicators. in this paper, the actual and complex issues of regional competitiveness have been analyzed, which has multiple interests in a large scale, particularly in our literature and practice. Given the fact that the issues of competitiveness and the regional policy are very important for Serbia, the correlation analysis of the indicators of regional competitiveness provides an opportunity to determine their relationships and interdependence. Policy makers can use the research in order to improve regional competitiveness if there is a significant correlation between these indicators. By influencing and investing in a particular indicator, the values of the other indicators highly and positively correlated with this indicator are indirectly enhanced. In addition, the indicators with low values are indicative for policy makers in that there are "potential bottlenecks of competitiveness".

This paper is limited in that it groups a certain (smaller) number of indicators. The other indicators of regional competitiveness (agriculture, the geo-location, the industry) have been omitted from the analysis. The results may not be incorrect because of this limitation, but they do not show the interdependence of all indicators. Although there are indicators with which it is absurd to examine correlation dependence, it does not mean they should be excluded from the measurement of competitiveness in the region. It can be concluded that of the majority of the indicators confirm the hypothesis, according to which there is

Table 5 The correlation of the key indicators of the social factors and tourism, according to Pearson's correlation coefficient

\begin{tabular}{|c|c|c|c|c|c|}
\hline & $\begin{array}{l}\text { The total of } \\
\text { water supply }\end{array}$ & $\begin{array}{l}\text { Investments in water } \\
\text { supply }\end{array}$ & $\begin{array}{l}\text { The number of } \\
\text { housings }\end{array}$ & $\begin{array}{c}\text { The number of } \\
\text { tourists }\end{array}$ & $\begin{array}{l}\text { The average } \\
\text { net salary in the } \\
\text { region }\end{array}$ \\
\hline \multirow[t]{2}{*}{$\begin{array}{l}\text { The amount of } \\
\text { hazardous waste in } \\
\text { the region }\end{array}$} & $-0,600$ & 0,975 & $-0,518$ & $-0,355$ & $-0,424$ \\
\hline & $\begin{array}{l}\text { The total of } \\
\text { water supply }\end{array}$ & The number of housings & $\begin{array}{l}\text { The prevalence } \\
\text { of corruption }\end{array}$ & $\begin{array}{l}\text { The length of } \\
\text { contemporary } \\
\text { roadways }\end{array}$ & $\begin{array}{l}\text { The quality of } \\
\text { railways }\end{array}$ \\
\hline $\begin{array}{l}\text { The number of } \\
\text { tourists }\end{array}$ & 0,676 & 0,098 & $-0,429$ & 0,234 & 0,254 \\
\hline
\end{tabular}


a correlation between the selected indicators. The growth of the number of employees and companies in the region has a nearly absolutely positive correlation with the GDP growth (Pearson's correlation coefficient is 0.99). This fact shows that the employment growth and entrepreneurship policy is very important when the economy or the region is concerned. When compared with the growth of employment in the region, expenditures in education have shown an almost identical match. The government investment in education does not only reduce unemployment, but it also indirectly affects a future growth of the GDP. A perfect correlation (Coefficient 1) exists between the interdependence of the clusters, the attractiveness of the business environment and the quality of the government services. Even though it only refers to the three mentioned indicators, which undoubtedly indicate the absolute interdependence, their development and strengthening have required many reforms and a long-lasting process of improving the business environment. The analysis also points out the great importance of investing in science and innovation. These indicators show that an increase in investment in scientific research and innovation have a significant influence (coefficient 0.9) on the GDP growth in the region. Finally, the results could initiate the theoretically-methodological and practical issues related to an increase in the value of some indicators of regional competitiveness as well as the competitive policies in Serbia.

\section{ACKNOWLEDGMENTS}

The paper is the result of Project no. 47007/III, funded by the Ministry of Education, Science and Technological Development of the Republic of Serbia.

\section{REFERENCES}

Agencija za privredne registre. (2012). Registar privrednih subjekata. (Baza podataka ažurirana jul-avgust 2012).

Annoni, P., \& Kozovska, K. (2010). EU Regional Competitiveness Index 2010. European Commission, Joint Research Centre,
Institute for the Protection and Security of the Citizen, Luxembourg. DOI 10.2788/88040

Boschma, R. A. (2004). The competitiveness of regions from an evolutionary perspective. Regional Studies, 38(9), 1001-1014. DOI: $10.1080 / 0034340042000292601$

Bristow, G. (2005). Everyone's a 'winner': problematising the discourse of regional competitiveness. Journal of Economic Geography, 5, 285-304. DOI: 10.1093/jeg/lbh063

Cho, D. S. (1994). The nine factor model. Reprinted in Cho, D. S., \& Moon, C. H. (2005). From Adam Smith to Michael Porter. Evolution of Competitiveness Theory. Asia-Pacific Business Series, 2, 135-160. DOI: 10.1142/9789814401661_0006

Cho, D. S., \& Moon, H. C. (2000). From Adam Smith to Michael Porter: Evolution of Competitiveness Theory. Korea: AsiaPacific Business Series. DOI: 10.1142/9789814401661_0003

Cooke, P. (2004). Competitiveness as cohesion: Social capital and the knowledge economy. In: Boddy, M. \& Parkinson, M. City Matters: Competitiveness, Cohesion and Urban Governance. 153-170. DOI:10.1332/policypress/9781861344458.003.0009

de Vet, J. M., Baker, P., Dalgleish, K., Pollock, R., \& Healy, A. (2004). The competitiveness of places and spaces: A Position Paper / Rotterdam / Leeds / Birmingham / Brussels.

Domanović, V. (2013). Efektivnost sistema merenja performansi u uslovima savremenog poslovnog okruženja. Ekonomski horizonti, 15(1), 31-44. DOI: 10.5937/ekonhor1301031D

European Commission. (1999). Sixth Periodic Report on the Social and Economic Situation of Regions in the EU. Brusel.

European Commission. (2001). Second Report on Economic and Social Cohesion. Brusel.

European Commission. (2003). In R. L. Martin (Ed.), A Study on the Factors of Regional Competitiveness. Draft final report for The European Commission Directorate-General Regional Policy. Bruselas: Cambridge Econometrics. Ecorys-NEI.

Freudenberg, M. (2003). Composite indicators of country performance: A critical assessment. STI working paper, 16, 2-34. DOI: $10.1787 / 405566708255$

Gardiner, G., Martin, R., \& Tyler, P. (2004). Competitiveness, productivity and economic growth across the European regions. Regional Studies 38(9), 1045-1068. DOI: 10.1080/0034340042000292638

Giovannini, E., Nardo, M., Saisana, M., Saltelli, A., Tarantola, S., \& Hoffman, A. (2005). Constructing Composite Indicators: Methodology and User Guide. OECD Statistics Working Paper, STD/DOC OECD publishing. DOI: 10.1787/18152031 
Huggins, R. (2003). Creating a UK Competitiveness Index: Regional and Local Benchmarking. Regional Studies, 37, 8996. DOI: $10.1080 / 0034340022000033420$

Huovari, J., Kangasharju, A., \& Alanen, A. (2001). Constructing an index for regional competitiveness. Pellervo Economic Research Institute Working Papers, Helsinki, 44. DOI: 10.1007/978-3-540-24823-1_7

IMD. (2000). The World Competitiveness Yearbook 2000. Lausanne.

IMD. (2004). The World Competitiveness Yearbook 2004. Lausanne.

Joksimović, Lj. (2008). Spiloveri stranih direktnih investicija i razvoj ljudskog kapitala: Tranzicione ekonomije i Srbija. U V. Babić, Lj. Maksimović (Ur.), Inostrani kapital kao faktor razvoja zemalja u tranziciji (str. 77-95). Kragujevac, Srbija: Ekonomski fakultet Univerziteta u Kragujevcu.

Kern, J. (2005). Je konkurencieschopnost regionu podmínkou jejich efektívniho rozvoje? In: New members - New Challenges for the European Regional Development Policy.

Kitson, M., Martin, R. \& Tyler, P. (2004). Regional Competitiveness: An Elusive yet Key Concept?, Regional Studies, 38(9), 991-999. DOI: 10.1080/0034340042000320816

Krugman, P. (1990). The Age of Diminished Expectations. Cambridge MA: MIT Press. DOI: 10.1177/027046769201200251

Krugman, P. (1994). Competitiveness: A Dangerous Obsession. Foreign Affairs, 73(2), 28-44. http://www.jstor.org/discover/10 .2307/20045917? uid=3738928\&uid=2134\&uid=2\&uid=70\&uid $=4 \&$ sid $=21103026428461$

Krugman, P. (1996). Making sense of the competitiveness debate. Oxford Review of Economic Policy, 12(3), 17-25. DOI: 10.1093/oxrep/12.3.17

Leković, V. (2012). Poverenje kao institucionalni faktor ekonomske uspešnosti. Ekonomski horizonti, 14(2), 65-75. DOI: 10.5937/ekonhor1202063L

Lengyel, I. (2004). The pyramid model: enhancing regional competitiveness in Hungary. Acta Oeconomica, 54(3), 323342. DOI: 10.1556/AOecon.54.2004.3.3

Martin, R. (2005). A Study on the Factors of Regional Competitiveness. A draft final report for the European Commission Directorate-General Regional Policy. European Commission.

Martin, R., Kitson, M., \& Tyler, P. (2006). Regional Competitiveness. London, UK: Routledge. DOI: 10.1177/00420980070440110905

Meyer-Stamer, J. (2008). Systematic Competitiveness and Local Economic Development. In Shamin Bodhanya (Ed.), Large Scale Systemic Change: Theories, Modelling and Practices.
Organisation for Economic Cooperation and Development (OECD). (1997). Regional Competitiveness and Skills. Paris, France: OECD.

Powell, T. C. (2001). Competitive advantage: logical and philosophical considerations. Strategic Management Journal, 22(9), 875-888. DOI: 10.1002/smj.173

Porter, M. (1990). The Competitive Advantage of Nations. London, UK: MacMillan Press. DOI: 10.1002/cir.3880010112

Porter, M. (1992). Competitive Advantage: Creating and Sustaining Superior Performance. Issue 10. PA Consulting Group, London. DOI: 10.1590/s0034-75901985000200009

Porter, M. (1998). On Competition. Boston, USA: Harvard Business School.

Reiljan, J., Hinrikus, M., \& Ivanov, A. (2000). Key issues in defining and analysing the competitiveness of a country. Working Paper Series. University of Tartu, Faculty of Business and Administration, 1, 59 DOI: 10.2139/ssrn.418540

Republički zavod za statistiku. (2011a). Statistički godišnjak Republike Srbije. Beograd.

Republički zavod za statistiku. (2011b). Naučnoistraživačka delatnost $u$ Republici Srbiji, 2010. Beograd.

Republički zavod za statistiku. (2011c). Opštine $i$ regioni u Republici Srbiji. Beograd.

Republički zavod za statistiku. (2012a). Statistički kalendar Republike Srbije. Beograd.

Republički zavod za statistiku. (2012b). Anketa o radnoj snazi, 2011. Beograd.

Rugman, A. M., Moon, C. H., \& Verbeke, A. (1998). The Generalized Double Diamond Model. Reprinted in Cho, D. S., \& Moon, C. H. (2005). From Adam Smith to Michael Porter. Evolution of Competitiveness Theory. Asia-Pacific Business Series, 2, 111-133. DOI: 10.1142/9789814401661_0005

Ručinska, S., \& Ručinsky, R. (2007). Factors of regional competitiveness. 2nd Central European Conference in Regional Science - CERS, 2007. Technical University of Košice, Faculty of Economics.

Schwab, K., \& Porter, M. E. (2007). The Global Competitiveness Report 2007-2008. Geneva, Switzerland: World Economic Forum.

Saisana, M., Tarantola, S., Schulze, N., Cherchye, L., Moesen, W., \& Van Puyenbroeck, T. (2005). Knowledge Economy Indicators. State-of-the-Art Report on Composite Indicators for the Knowledge-based Economy. Workpackage 5. 
Snieška, V., \& Bruneckienè, J. (2009). Measurement of Lithuanian regions by regional competitiveness index. Engineering economics, 1(61).

Storper, M. (2005). Society, Community and Economic Development. Studies in Comparative International Development, 39(4), 30-57. DOI: 10.1007/BF02686164

Vuković, D., \& Wei, L. (2010). Regional competitiveness: the case of western China. Journal of Geographical institute "Jovan Crijic" of Serbian academy of sciences and arts, 60(1), 107-124. DOI: $911.2 / .3(51)$

Vuković, D., Jovanović, A., \& Đukić., M. (2012). Defining competitiveness through the theories of new economic geography and regional economy. Journal of Geographical institute "Jovan Cvijic" of Serbian academy of sciences and arts, 62(3), 49-64. DOI: 10.2298/IJGI1203049V
Vuković, D. (2012). Anketa, sprovedena za potrebe Doktorske disertacije.

Vuković, D. (2013). Model regionalne konkurentnosti: Teorijsko-metodološka analiza i mogućnosti primene u Srbiji. Nepublikovana doktorska disertacija, Ekonomski fakultet Univerziteta u Kragujevcu, Srbija.

Wignaraja, G., Lezama, M., \& Joiner, D. (2004). Small States in Transition: From Vulnerability to Competitiveness. United Kingdom: Commonwealth Secretariat. DOI: $10.1177 / 0047287510368139$

Ward Thompson, C. (2005). Who benefits from landscape architecture? In S. Harvey, \& K. Fieldhouse (Eds.), The Cultured Landscape: Designing the environment in the 21st century (pp. 95-124). Abingdon and New York, NY: Routledge.

Received on $9^{\text {th }}$ November 2013 , after revision,

accepted for publication on $17^{\text {th }}$ December 2013

Darko B. Vukovic is a research associate of the Geographical Institute "Jovan Cvijic" of the Serbian Academy of Sciences and Arts, in the field of regional economics and economic geography. He obtained his $\mathrm{PhD}$ at the Faculty of Economics, University of Kragujevac. The key areas of his scientific interest are regional economics, macroeconomics and international finance. 


\section{APPENDIX}

Table 6 The variables of the indicators for the economic factor

\begin{tabular}{|c|c|c|c|c|c|}
\hline Regions & $\begin{array}{l}\text { Regional GDP (mill. } \\
\text { RSD)* }\end{array}$ & $\begin{array}{c}\text { The number of } \\
\text { companies in the } \\
\text { region ** }\end{array}$ & $\begin{array}{l}\text { The number of } \\
\text { entrepreneurs } \\
\text { in the region ** }\end{array}$ & $\begin{array}{l}\text { The number of } \\
\text { employees in } \\
\text { the region* }\end{array}$ & $\begin{array}{l}\text { Investments in } \\
\text { capital assets * }\end{array}$ \\
\hline Serbia & 2986614 & 103548 & 20500 & 1746138 & 425400001 \\
\hline Belgrade & 1193867 & 45724 & 54239 & 576905 & 210458922 \\
\hline $\begin{array}{l}\text { Southern and East- } \\
\text { ern Serbia }\end{array}$ & 433502 & 11600 & 40371 & 305543 & 100024608 \\
\hline $\begin{array}{l}\text { Šumadija and } \\
\text { Western Serbia }\end{array}$ & 583366 & 15993 & 60595 & 403104 & 63607782 \\
\hline Vojvodina & 775879 & 26089 & 54935 & 460588 & 42280261 \\
\hline
\end{tabular}

Source: *The Statistical Office of the Republic of Serbia, 2012a; ** The Serbian Business Registers Agenc

Table 7 The variables of the indicators for the human resources factor

\begin{tabular}{lcccc}
\hline Regions & $\begin{array}{c}\text { Working-age population } \\
(16-64)\end{array}$ & $\begin{array}{c}\text { Population with } \\
\text { higher education } \\
(\%)\end{array}$ & $\begin{array}{c}\text { Budgetary expendi- } \\
\text { tures in education (in } \\
\text { 000 RSD) }\end{array}$ & $\begin{array}{c}\text { Investments in education } \\
\text { (in 000 RSD) }\end{array}$ \\
\hline $\begin{array}{l}\text { Serbia } \\
\text { Belgrade }\end{array}$ & 4775996 & 9,5 & 140002218 & 3901604 \\
$\begin{array}{l}\text { Southern and Eastern } \\
\text { Serbia } \\
\text { Šmadija and Western }\end{array}$ & 1047347 & 7 & 41860479 & 1063191 \\
$\begin{array}{l}\text { Serbia } \\
\text { Vojvodina }\end{array}$ & 1088708 & 7 & 26040688 & 859503 \\
\hline
\end{tabular}

Source: The Statistical Office of the Republic of Serbia (2011c, 2012b) 
Table 8 The variables of the indicators for the innovations factor

\begin{tabular}{|c|c|c|c|}
\hline Regions & $\begin{array}{l}\text { The number of organizations en- } \\
\text { gaged in } R \& D \text { * }\end{array}$ & $\begin{array}{c}\text { The number of employees } \\
\text { engaged in R\&D* }\end{array}$ & $\begin{array}{l}\text { Expenditures for R\&D } \\
\text { (in } 000 \mathrm{RSD}) *\end{array}$ \\
\hline Serbia & 271 & 20067 & 24944966 \\
\hline Belgrade & 160 & 11384 & 18109050 \\
\hline $\begin{array}{l}\text { Southern and Eastern } \\
\text { Serbia }\end{array}$ & 34 & 2115 & 998815 \\
\hline $\begin{array}{l}\text { Šumadija and Western } \\
\text { Serbia }\end{array}$ & 32 & 1332 & 1137281 \\
\hline Vojvodina & 45 & 5236 & 4699820 \\
\hline Regions & $\begin{array}{l}\text { The total number of scientific } \\
\text { papers * }\end{array}$ & $\begin{array}{l}\text { Investments in Innovation } \\
\text { (in } 000 \mathrm{RSD}) * * *\end{array}$ & $\begin{array}{l}\text { The number of regis- } \\
\text { tered patents** }\end{array}$ \\
\hline Serbia & 7034 & 26543143 & 93 \\
\hline Belgrade & 5044 & 21089554 & 26 \\
\hline $\begin{array}{l}\text { Southern and Eastern } \\
\text { Serbia }\end{array}$ & 402 & 1039094 & 2 \\
\hline $\begin{array}{l}\text { Šumadija and Western } \\
\text { Serbia }\end{array}$ & 357 & 1767264 & 5 \\
\hline Vojvodina & 1231 & 2647231 & 60 \\
\hline
\end{tabular}

Source: The Statistical Office of the Republic of Serbia (* 2011a; ${ }^{* *} 2011 b ;{ }^{* * *}$ 2011c)

Table 9 The variables of the indicators for the social factor

\begin{tabular}{lcc}
\hline Regions & $\begin{array}{c}\text { The number of } \\
\text { housings }\end{array}$ & $\begin{array}{c}\text { The prevalence } \\
\text { of corruption } \\
\text { (in \%) }\end{array}$ \\
\hline Serbia & 3243587 & 9,3 \\
Belgrade & 739630 & 10,9 \\
$\begin{array}{l}\text { Southern and } \\
\text { Eastern Serbia }\end{array}$ & 748731 & 9,9 \\
$\begin{array}{l}\text { Sumadija and } \\
\text { Western Serbia }\end{array}$ & 902997 & 6,7 \\
Vojvodina & 852229 & 9,9 \\
\hline
\end{tabular}

ISource: The Statistical Office of the Republic of Serbia (2012a)
Table 10 The variables of the indicators for the culture-and-tourism factor

\begin{tabular}{lcc}
\hline Regions & $\begin{array}{c}\text { The number of } \\
\text { tourists }\end{array}$ & $\begin{array}{c}\text { Total overnight } \\
\text { stays of tourists }\end{array}$ \\
\hline Serbia & 2000597 & 6413515 \\
Belgrade & 618454 & 1319629 \\
$\begin{array}{l}\text { Southern and } \\
\text { Eastern Serbia }\end{array}$ & 392044 & 2649943 \\
$\begin{array}{l}\text { Sumadija and } \\
\text { Western Serbia }\end{array}$ & 663208 & 2516236 \\
Vojvodina & 281842 & 767304 \\
\hline
\end{tabular}

Source: The Statistical Office of the Republic of Serbia (2011c) 
Table 11 The perception indicators, according to experts

\begin{tabular}{lcccc}
\hline Regions & $\begin{array}{c}\text { The extent } \\
\text { of the clus- } \\
\text { ters }\end{array}$ & $\begin{array}{c}\text { Connectivity of air trans- } \\
\text { portation with foreign } \\
\text { countries }\end{array}$ & $\begin{array}{c}\text { The quality } \\
\text { of railways }\end{array}$ & $\begin{array}{c}\text { The quality of the electro- } \\
\text { energy infrastructure }\end{array}$ \\
\hline Serbia & 100 & 100 & 100 & 100 \\
Belgrade & 124,19 & 218,63 & 122,38 & 143,09 \\
Southern and Eastern Serbia & 75,00 & 61,75 & 68,29 & 72,00 \\
Šumadija and Western Serbia & 85,43 & 48,06 & 74,78 & 85,93 \\
Vojvodina & 98,83 & 49,45 & 91,42 & 105,01 \\
\hline
\end{tabular}

Source: Vuković, 2012

Table 12 The perception indicators, according to experts

\begin{tabular}{|c|c|c|c|c|c|c|}
\hline Regions & $\begin{array}{l}\text { Confidence } \\
\text { in business } \\
\text { institutions }\end{array}$ & $\begin{array}{l}\text { Safety of } \\
\text { property } \\
\text { rights }\end{array}$ & $\begin{array}{l}\text { The share of the } \\
\text { gray economy in } \\
\text { business activities }\end{array}$ & $\begin{array}{l}\text { The inde- } \\
\text { pendence of } \\
\text { the judiciary }\end{array}$ & $\begin{array}{c}\text { The attractiveness } \\
\text { of the business } \\
\text { environment }\end{array}$ & $\begin{array}{l}\text { Quality of } \\
\text { state ser- } \\
\text { vices }\end{array}$ \\
\hline Serbia & 100 & 100 & 100 & 100 & 100 & 100 \\
\hline Belgrade & 100,31 & 91,79368 & 103,44 & 83,81211 & 193,71 & 121,6984 \\
\hline $\begin{array}{l}\text { Southern and Eastern } \\
\text { Serbia }\end{array}$ & 76,02 & 88,39 & 93,20 & 74,39 & 64,77 & 72,73 \\
\hline $\begin{array}{l}\text { Šumadija and Western } \\
\text { Serbia }\end{array}$ & 85,94 & 88,95 & 86,72 & 79,33 & 94,20 & 88,14 \\
\hline Vojvodina & 93,49 & 94,36 & 83,15 & 85,62 & 126,14 & 97,97 \\
\hline
\end{tabular}

Source: Vuković, 2012 


\title{
KORELACIONA ANALIZA INDIKATORA REGIONALNE KONKURENTNOSTI: PRIMER REPUBLIKE SRBIJE
}

\author{
Darko B. Vuković* \\ Geografski institut „Jovan Cvijić, Srpske akademije nauka i umetnosti (SANU)
}

Identifikacija i analiza indikatora regionalne konkurentnosti predstavlja najvažniju fazu procesa merenja konkurentnosti. Međutim, pre samog merenja, neophodno je utvrditi da li postoji visoka korelacija između izabranih indikatora. Cilj ovog istraživanja je da se utvrdi da li postoji visoka korelacija između najvažnijih indikatora regionalne konkurentnosti. Predmet istraživanja su indikatori konkurentnosti regiona $u$ Republici Srbiji (RS), čije se vrednosti mere u periodu 2011-2013. Za indikatore koji nisu srodni ili nemaju logički međusobni uticaj nije utvrđena korelacija. Na osnovu rezultata istraživanja, pokazalo se da postoji visoka korelacija između BDP-a regiona, broja privrednih društava u regionu, broja zaposlenih, raširenosti klastera, investicija u inovacije i poverenja u poslovne institucije. Korišćen je statistički metod procene, Pirsonov koeficijent korelacije. Oni podaci čije merenje nije moguće izvršiti kvantitativnim putem dobijeni su anketom.

Ključne reči: regionalna konkurentnost, indikatori regionalne konkurentnosti, korelaciona analiza indikatora regionalne konkurentnosti

JEL Classification: R10, R58, 018

\section{UVOD}

Teorija konkurentnosti je stara koliko i sama ekonomija kao naučna disciplina. Ne postoji nijedan predstavnik škole ekonomije koji nije dotakao problematiku konkurentnosti (bilo da su u pitanju međunarodna ekonomija, produktivnost, cene, ponašanje potrošača, itd.) Zbog toga se može reći da ekonomija, u modernom smislu, predstavlja borbu za neko tržište, uzimajući u obzir ekonomske zakone, principe i sve druge kategorije koje se izučavaju u ovoj

\footnotetext{
* Korespondencija: D.B. Vuković, Geografski institut „Jovan Cvijić" SANU, Đure Jakšića 9/3, 11000 Beograd, Srbija; e-mail: d.vukovic@gi.sanu.ac.rs
}

nauci. Posebno se može govoriti o makroekonomiji, ljudskim resursima, finansijama, međunarodnim odnosima, produktivnosti, odnosima sa kupcima itd, gde se svaka ova oblast ili kategorija može različito posmatrati i analizirati, ali gde se zajednički efekat manje-više svodi na "određeno svojstvo“ ili output koji će omogućiti bolju poziciju u odnosu na drugu firmu, grad, region ili državu.

Sam pojam konkurentnosti široko je rasprostranjen $\mathrm{u}$ ekonomskojliteraturi. Veliki broj ekonomista objašnjava je decenijama, može se čak reći i vekovima, sa ključnim pitanjem: Kako i što bolje razumeti problematiku koja je najznačajnija za rast ekonomskog bogatstva i najefikasnije načine njegove raspodele? Različiti 
autori definišu konkurenciju na nivou kompanija, privrede, regiona ili gradova, a zbog kompleksnosti ovog termina, ne postoji opšteprihvaćena definicija. Siri pojam konkurentnosti odnosi se na sklonost i veštinu takmičenja, mogućnost da se osvoji i zadrži tržišna pozicija, poveća tržišno učešće i profitabilnost - dakle, pojam konkurentnosti označava uspešnost u poslovanju. Zbog složenosti koncepta, raznovrsnosti faktora i prirode konkurentskih procesa, termin konkurentnosti je težak i često zbunjujući, posebno na regionalnom nivou (Snieška \& Bruneckienè, 2009). Nivo na kom se konkurentnost definiše, predstavlja najvažniji aspekt ovog koncepta (Annoni \& Kozovska, 2010; Kitson et al, 2004). Indikatori regionalne konkurentnosti pružaju važne informacije o "snazi“ regiona da: ostvari adekvatan ekonomski rezultat, obezbedi odgovarajuću socijalnu brigu, kvalitetnu infrastrukturu, generiše inovacije, razvija ljudski kapital, poseduje geografski i prirodni potencijal, raspolaže adekvatnim institucijama, neguje kulturu i razvija turizam. Identifikovanjem ovih indikatora, i njihovom selekcijom i analizom, moguće je meriti konkurentnost.

Predmet ovog rada su indikatori konkurentnosti, koji se posmatraju za regione u Republici Srbiji: Šumadija i Zapadna Srbija, Beograd, Vojvodina, Istočna i Zapadna Srbija, kao i za region Kosovo i Metohija (za koji ne postoje podaci, ili su teško dostupni), u periodu 2011-2013. Cilj je da se utvrdi korelaciona zavisnost posmatranih indikatora. Rad se ne bavi pitanjem vrednosti indikatora i njihovim poređenjem sa istim indikatorima konkurenata, već njihovom korelacionom zavisnošću. Merenje indikatora i njihova analiza imaju potpun naučni i praktični značaj samo u slučaju visoke korelacije indikatora konkurentnosti. Takva korelacija treba da postoji za srodne, ili povezane indikatore, a ne za sve grupe indikatora. Na primer, očekuje se visok stepen korelacije između grupe ekonomskih indikatora (visoka zaposlenost korelisana je rastom BDP-a), ili institucionalnih indikatora (kvalitet poslovnog okruženja je pozitivno korelisan rastom broja preduzeća), ali se ne očekuje da ti indikatori imaju pozitivnu korelaciju sa indikatorima prirodne sredine ili socijalnim indikatorima (visoka korelacija između indikatora broja stanova i količine otpadnih voda). Na osnovu definisanog cilja istraživanja, ovaj rad polazi od sledeće hipoteze:
$\mathrm{H}$ : Postoji korelaciona zavisnost indikatora regionalne konkurentnosti

Plan rada je sledeći: nakon uvodnog dela u kome se definišu problem istraživanja i postavlja hipoteza, predstavljena je teorijska osnova, sa osvrtom na međunarodnu literaturu. Nakon toga, u posebnoj sekciji, objašnjena je metodologija istraživanja. Na kraju, predstavljeni su rezultati i zaključak o istraživanom problemu. Podaci koji reprezentuju vrednosti indikatora dobijeni su na sledeći način: a) kvantitativni podaci preuzeti su od Republičkog zavoda za statistiku, Narodne banke Srbije i Agencije za privredne registre; b) kvalitativni podaci dobijeni su putem ankete.

\section{TEORIJSKA OSNOVA}

Ekonomija cele zemlje, tako i sveta, direktno zavisi od ekonomske i socijalne održivosti regiona i njihove sposobnosti da budu konkurentni. Ukoliko primenjene strategije regionalne konkurentnosti nisu efikasne i kada se faktori konkurentnosti ne koriste u potpunosti, tada će regioni (ili region) izgubiti svoju konkurentsku poziciju i postojaće negativan uticaj na nacionalnu konkurentnost (Vuković, 2013). Da bi se izbegla moguća opasnost gubitka konkurentske pozicije, neophodno je meriti regionalnu konkurentnost. Zbog toga je merenje konkurentnosti najvažnija faza u strateškom planiranju unapređenja regionalne i nacionalne konkurentnosti. Uprkos sve većem interesu akademske zajednice za problem regionalne konkurentnosti (Porter, 1990; Rugman et al, 1998; Cho \& Moon, 2000; Reiljan et al, 2000; European Commission - EC, 1999, 2001; Gardiner et al, 2004; Martin, 2005; Lengyel, 2004; Houvari et al, 2001; OECD 1997; Boschma, 2004; Cho, 2005; Vuković $i$ ostali, 2012), teorijska objašnjenja ovog koncepta spadaju među najteža i najkomplikovanija u ekonomiji.

Konkurentnost regiona može se izraziti na različite načine: analizirajući jedan ili više faktora konkurentnosti, upotrebom teorijskih modela konkurentnosti, stvaranjem kompozitnih indeksa, kombinacijom više metoda i sl. Prilikom merenja regionalne konkurentnosti, brojni autori (Lengyel, 2004; Kitson et al, 2004; de Vet et al, 2004; Huggins, 2003) pokazali su da se konkurentnost ne može 
bazirati na merenju samo ekonomskih i socijalnih faktora i njihovih indikatora, već se mora pristupiti višefaktorskom, kompleksnom merenju (Freudenberg, 2003; Wignaraja et al, 2004; IMD, 2004; Giovannini et al, 2005; Saisana et al, 2005; Huggins, 2003; Snieška \& Bruneckienė, 2009; Vuković, 2013). Dakle, identifikacija indikatora regionalne konkurentnosti, koji su sastavni deo faktora regionalne konkurentnosti, predstavlja najvažniji aspekt analize regionalne konkurentnost.

Kako se u međunarodnoj literaturi definiše konkurentnost? Makroekonomski koncept konkurentnosti je teško definisati i sadrži mnoge kontroverze (European Commission, 2003). Uprkos činjenici da je poboljšanje privredne ili regionalne konkurentnosti često predstavljano kao glavni cilj ekonomske politike, nedostatak opšteprihvaćene definicije je važan argument koji govori da je opasno vezivati centralnu politiku za problematiku konkurentnosti. P. Krugman (1994) ide još dalje, smatrajući da je koncept nacionalne konkurentnosti besmislen, nazivajući je "opasnom opsesijom" zbog tri ključna razloga:

- Obmanjujuće je i netačno da se pravi analogija između nacije (privrede) i firme. Na primer, neuspešne firme biće istisnute sa tržišta, ali takav bottom line ekvivalent ne postoji za naciju.

- Kada se firme takmiče za tržišni udeo, onda se uspeh jedne firme stvara na uštrb manje uspešnosti druge (koja trpi veće troškove). Ovo pravilo se ne može primeniti za nacionalne privrede, jer se uspeh neke privrede ili regiona pre poboljšava, nego što šteti međunarodnoj trgovini (drugim zemljama). Ovaj efekat se naziva zero sum igra.

- Ukoliko konkurentnost ima smisla, onda je to jednostavno drugi način da se izrazi produktivnost. Rast životnog standarda u nekoj državi suštinski zavisi od stope rasta produktivnosti.

Prema definiciji Svetskog ekonomskog foruma, konkurentnost predstavlja skup institucija, politika i faktora koji određuju nivo produktivnosti jedne zemlje (Schwab \& Porter, 2007). Na mikronivou, konkurentnost predstavlja sposobnost firmi da se takmiče, rastu i budu profitabilne (Martin et al, 2006; Powell, 2001), ili sposobnost firme da proizvede i proda proizvode i usluge po ceni koja je niža od konkurentskih, ili uz druge necenovne faktore koji su atraktivniji od konkurentske ponude (IMD, 2000). Odnosno, konkurentnost se definiše kao sposobnost kompanije da dosledno i profitabilno proizvodi output koji zadovoljava zahteve otvorenog tržišta u pogledu cene, kvaliteta, itd. Najčešće, mikronivo konkurentnosti se odnosi na performanse kompanije (Domanović, 2013). Iako se radi o dva različita aspekta, dva pogleda na konkurentnost, između makro i mikro nivoa postoji snažna i direktna veza (Schwab \& Porter, 2007). Mnogi autori, među kojima je i Krugman (1994, 1996), smatraju da se definicija konkurentnosti odnosi na produktivnost koja meri vrednost roba i usluga po jedinici faktora proizvedenih na određenoj teritoriji. Prema ovim autorima, konkurentnost ima za cilj postizanje veće produktivnosti koja utiče na rast životnog standarda građana.

Između makro- i mikronivoa konkurentnosti, definiše se koncept regionalne konkurentnosti. Prema izvornom značenju, obuhvaćenom Globalnim indeksom konkurentnosti (Svetski ekonomski forum), može implicitno da se razume da je regionalna konkurentnost nivo i kvalitet života u jednom regionu. Takođe, regionalna konkurentnost se može izraziti kao sposobnost privlačenja faktora proizvodnje. Pojam regionalne konkurentnosti ne može se iskazati ni kao makro-, ali ni kao mikroekonomska odrednica, jer regioni nisu prosto umanjena verzija određene nacije ili samo agregatni izraz firmi $u$ regionalnom prostoru (Ward, 2005; Gardiner et al, 2004). Dakle, konkurentnost na regionalnom nivou ne rezultira samo iz makroekonomske stabilnosti ili iz preduzetništva na mikronivou, već iz novih obrazaca konkurentnosti koji imaju svoju regionalnu komponentu (Annoni \& Kozovska, 2010). Prema J. Meyer-Stamer-u (2008): Konkurentnost teritorije je sposobnost lokaliteta ili regiona da stvara visok i rastući prihod, kao i da poboljša životni standard ljudi koji na toj teritoriji žive. Ova definicija se fokusira na blisku vezu između regionalne konkurentnosti i regionalnih prosperiteta, karakterišući konkurentnost ne samo terminima „izlaznih relacija“, kao što je produktivnost, već i u ukupnim privrednim performansama (Bristow, 2005). R. Huggins (2003) ističe da se lokalna i regionalna konkurentnost javljaju samo kada se postigne 
održiv rast u cenama rada, što utiče na rast životnog standarda.

Definisanje termina regionalne konkurentnosti predstavlja veoma težak zadatak, jer još uvek ne postoji opšteprihvaćena definicija (Vuković \& Wei, 2010). Jedna od najčešce upotrebljavanih definicija, ili je možda pravilnije reći najmanje osporavana, jeste definicija European Commission (1999), kojm se konkurentnost regiona definiše kao njegova sposobnost da proizvede robu i usluge koji zadovoljavaju međunarodne tržišne kriterijume dok, u isto vreme, održava visok i održiv nivo prihoda. Opštije rečeno, konkurentnost regiona je njegova sposobnost da proizvodi dok je istovremeno izložen spoljnoj konkurenciji, uz relativno visoke nivoe dohotka i zaposlenosti.

Prema M. Porter-u (1990), ukoliko država kreira takav poslovni ambijent gde postoje povoljni uslovi za biznis i gde država daje maksimalnu podršku kompanijama da obavljaju operacije na lokalnim i globalnim tržištima, ovi uslovi predstavljaju konkurentsku prednost nacije. Prema istom autoru, ova tvrdnja može se primeniti i na nivo regiona. P. Krugman se ne slaže sa M. Porter-om: „Ideja da blagostanje i ekonomske perfomanse jedne države zavise od uspeha na svetskom tržištu je hipoteza i ne znači nužno istinu, štaviše, kroz praktičan i empirijski pogled ova hipoteza je potpuno pogrešna" $(1994,30)$. Isti autor smatra da se svetske vodeće nacije ne takmiče jedne s drugima i da ne postoji „značajan stepen konkurentnosti“ među njima. Mnogi autori (Krugman, 1994; Kern, 2005, 173; Ručinska \& Ručinsky, 2007, 904) smatraju da se konkurencija između kompanija i regiona ne može porediti. Kompanije mogu ući ili izaći sa tržišta u odnosu na njihovu uspešnost, ali regioni ne mogu da napuste svoje teritorije bez obzira na svoju uspešnost. Na osnovu toga moguće je istaći osnovnu razliku između konkurentnosti kompanije i regiona: Kompanije se bore međusobno i mogu poboljšati svoju poziciju na tržištu tako što će istisnuti drugu kompaniju (kompanije) ili pogoršati poziciju te druge kompanije (Pareto optimum) dok regioni mogu da poboljšaju svoje pozicije istovremeno, a da ne ugrožavaju pozicije drugih regiona.

Konkurentnost regiona može se posmatrati na dva načina: prvo, preko specifičnih pokretača, koji regionu pružaju mogućnost da koristi svoje konkurentske prednosti i da se takmiči sa drugim regionima i drugo, preko rezultata (dohotka) koje ostvaruje upotrebom specifičnih faktora $\mathrm{i}$ indikatora. Imajući $\mathrm{u}$ vidu prethodno rečeno, jedan deo radova upravo govori o konkurentnosti koja se bazira na kumulativnom razultatu, stvorenom na osnovu egzistencije različitih faktora i njihovih indikatora koje region poseduje, dok drugi deo radova analizira upravo pomenute regionalne pokretače (Ručinska \& Ručinsky, 2007). Ovi pokretači regionalne konkurentnosti, ili drugačije rečeno, nasleđeni uslovi konkurentnosti, predstavljaju regionalnu opremljenost, što region upravo čini specifičnim: infrastrukturni objekti, bezbednost, tehničke karakteristike regiona, prirodni resursi, nivo i obim usluga, broj preduzeća, kvalitet i raspoloživost radne snage, broj i kvalitet obrazovnih ustanova, kvalitet javne administracije, istorijski okvir regiona. Kada se konkurentnost bazira na određenom rezultatu, onda se govori o regionalnim pokazateljima ekonomskog razvoja, kao što su: regionalni BDP po stanovniku, stopa nezaposlenosti, prosečna plata, priliv stranih direktnih investicija, inovacije (Joksimović, 2008) i sl. Pokretači konkurentnosti mogu biti i neopipljivi indikatori, kao što je poverenje. Prema V. Lekoviću (2012), bez poverenja nisu moguće investicije, transakcioni troškovi rastu, što, u skladu s tim, stvara ozbiljne prepreke tokom funkcionisanja i razvoja. Isto tako, kao indikatori često se koriste neformalne institucije, kvalitet poslovnog okruženja, raširenost klastera i drugi indikatori koji se vode kao „neopipljivi“.

\section{METODOLOGIJA}

Metodom statističke analize obuhvaćen je veći broj podataka neophodnih za određivanje vrednosti indikatora. Ovi podaci se odnose na: strukturu stanovništva, obrazovanje, fizičku infrastrukturu, patente, naučne projekte $\mathrm{u}$ zemlji i inostrantvu, bruto domaći proizvod (BDP), privredne subjekte, pokrenute i završene stečajne postupke, produktivnost radnika, stope zaposlenosti $\mathrm{i}$ nezaposlenosti, investicije $\mathrm{u}$ osnovna sredstva, bruto zarade, potrošnju, turističke objekte, itd. Na osnovu rezultata popisa Republičkog zavoda za statistiku, Agencije za privredne registre, 
Geodetskog zavoda i drugih relevantnih institucija Republike Srbije, prikupljena je znatna količina podataka za istraživanje. Oni podaci koji nisu obuhvaćeni popisom ovih institucija, predstavljali su uzorak kreiran anketnim putem. Podaci su se prikupljali isključivo tehnikama, instrumentima i postupcima statističkog metoda. Ovom metodom prikupljali su se kako kvantitativni, tako i kvalitativni podaci. Opštenaučni statistički metod suočava se sa svim vrstama podataka koji se mogu izraziti numeričkim pokazateljima, tj. svi oni koji mogu biti kvantitativno izraženi. Istovremeno, za svaki kvantifikovani iskaz vezuje se merenje, tako da se ova opštenaučna metoda skoro poistovećuje sa merenjem. Sakupljeni podaci iskazuju određena svojstva (ili kvalitete) u određenoj količini (kvantitete) u određenom vremenu (hronološki) i na određenom prostoru (geografski).

Koeficijent korelacije je često upotrebljavan statistički metod koji pokazuje povezanost između promenljivih vrednosti. Korelaciona analiza ne govori o svim svojstvima veza koje otkriva, već samo o postojanju i učestalosti tih veza. Ova analiza spada u najsloženije analize. Vrednost korelacije utvrđuje se merenjem koeficijenta korelacije koji predstavlja numeričku vrednost kojom se označava stepen povezanosti između dve promenliive pojave. Ova vrednost se kreće od -1 do +1 . U ovom radu, koeficijent korelacije je obračunat pomoću programa The Statistical Package for the Social Sciences (SPSS), kao Pirsonov i Spirmanov koeficijent. Spirmanov koeficijent rang korelacije je neparametarski ekvivalent Pirsonovom koeficijentu linearne korelacije. Razlika između ova dva koeficijenta je $u$ tome, što se računske operacije ne izvode iz numeričkih vrednosti zavisne i nezavisno promenljive pojave, već iz njihovih relativnih odnosa tj. rangova.

Spirmanov koeficijent korelacije izračunava se kao:

$\sigma=1-\left[6 \sum \mathrm{d}^{2} / \mathrm{n}\left(\mathrm{n}^{2}-1\right)\right]$

gde su: $\sigma$ - Spirmanov keoficijent korelacije, d razlika između rangova $\mathrm{x}$ i $\mathrm{y}, \mathrm{n}$ - broj parova rangova promenljivih $\mathrm{x}$ i y. I ovaj koeficijent korelacije uzima vrednost od -1 do 1 .

Razlika između Pirsonovog koeficijenta proste linearne korelacije i Spirmanovog koeficijenta rang korelacije je $u$ tome što se ovaj poslednji može izračunati iz podataka, kada je merenje vršeno na ordinalnoj skali. Spirmanov koeficijent može da zameni Pirsonov, ako se intervalni podaci prevedu $u$ ordinalne tj. ako se rangiraju po veličini. Obrnuto, ako su podaci dati $u$ ordinarnoj skali, može se primeniti samo Spirmanov koeficijent. Statistička snaga Pirsonovog koeficijenta je znatno veća u odnosu na Spirmanov i ukoliko su podaci dati intervalno, prednost se daje Pirsonovom koeficijentu, a Spirmanov zbog lakoće izračunavanja treba primeniti samo kao probu. Svi podaci indikatora u okviru ovog istraživanja računati su po Pirsonovom koeficijentu, zbog njegove statističke snage. Kod korelacije važi opšte pravilo - što je vrednost koeficijenta proste linearne korelacije bliža jedinici, to je međuzavisnost među posmatranim pojavama jača.

Korelaciona analiza ima za cilj da prikaže povezanost između promenljivih vrednosti, odnosno, da li postoji zavisnost među indikatorima regionalne konkurentnosti. Korelaciona analiza ne sprovodi se radi utvrđivanja zavisnosti svih indikatora, već samo onih indikatora (tj. parova indikatora) za koje postoji smisao ili značaj merenja.

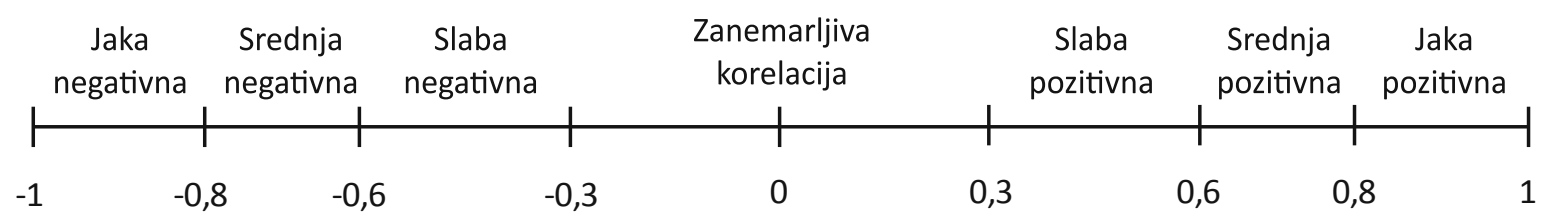

Slika 1 Skala tumačenja korelacije 
Prilikom identifikacije faktora i indikatora regionalne konkurentnosti, utvrđeno je da se određeni indikatori ne mogu dobiti dokumentovano (statističkim putem), već je neophodno kreiranje ankete, kao tehnike ispitivanja. Ova perceptivna tehnika ima ulogu da prikupi one podatke koje nije moguće prikupiti kvantitativnim putem ili ih je veoma teško meriti. Za svrhu istraživanja $u$ ovom radu, korišćena je anketa koja podrazumeva pismeno opštenje između anketara i anketiranog, relativno nestandardizovane forme. Neformalna ili nestandardizovana forma, odnosi se isključivo na modalitete odgovora koji se upisuju po slobodnoj proceni, gde je modalitet samo okvirno dat. Ipak, struktura pitanja je više formalizivana, jer se radi o većem broju pitanja - sa jasnim uputima i zahtevom za preciznim modalitetima odgovora. $U$ odnosu na podvrste ankete, ova anketa se sprovodila putem elektronske pošte. Uzorak, na kom se sprovodila anketa je efikasan i reprezentativan. Sastoji se od grupe eksperata koji su kompetetni za istraživanje. U ove eksperte spadaju: vladini eksperti, eksperti sa univerziteta i naučnih instituta, i eksperti iz kompanija (koje imaju regionalni uticaj ili regionalnu poslovnu politiku). S obzirom na to da se uzorak pažljivo birao, subjektivnost odgovora i mogućnost grešaka su svedene na minimum. Ovim putem su dobijeni značajni podaci za indikatore kvaliteta poslovnog okruženja i neformalnih institucija, koji se mogu meriti samo perceptivnim putem.

\section{REZULTATI ISTRAŽIVANJA}

U ovom radu analizirana je korelacija 37 indikatora regionalne konkurentnosti. Broj indikatora koji određuju faktore regionalne konkurentnosti je veći i obuhvata indikatore: geografske lokacije, poljoprivrede, industrijskih kapaciteta i druge indikatore koji utiču na konkurentnost nekog regiona. Ipak, zbog uporedivosti podataka i kompleksnosti analize većeg broja indikatora, ovo istraživanje se ograničava na grupu od 37 izabranih indikatora, koji su predstavljeni u narednim tabelama. Korelacija indikatora je analizirana upotrebom programa SPSS, gde su prethodno grupisani i obrađivani kvantitativni statistički i kvalitativni podaci (Anketa). Naredne tebele prikazuju samo vrednosti dobijenih koeficijenata korelacije.

Bruto domaći proizvod (BDP) regiona ima skoro savršenu pozitivnu korelaciju sa indikatorom Broj privrednih društava u regionu (veoma blizu 1). Pirsonov koeficijent od 0,998 govori, da povećanje broja privrednih društava uvek utiče na povećanje BDP-a tog regiona (Tabela 1). Slično je i sa indikatorom Broj zaposlenih $\mathrm{u}$ regionu. Iako je ovaj indikator $\mathrm{u}$ neznatno manjoj korelaciji sa indikatorom BDP-a, korelacija je pozitivna i veoma jaka. To znači da rast zaposlenosti $u$ nekom regionu ima veliki uticaj na rast BDP-a. Investicije u osnovna sredstva imaju srednjepozitivnu korelaciju. Rast investicija, svakako, utiče na rast BDP-a, ali ne u meri koju imaju privredna društva i broj zaposlenih. Indikator koji se odnosi na broj preduzetnika u regionu slabo je koreliran sa indikatorom BDP-a, što znači da u manjoj meri utiče na njegov rast. Korelaciona analiza ovih indikatora pokazala je logičke, očekivane rezultate.

Kada je u pitanju indikator zaposlenosti (Tabela 2), postoji pozitivna korelacija sa indikatorom budžetski rashodi u obrazovanje. Ova veza govori o tome da veća ulaganja države u obrazovanje utiču na rast zaposlenosti. Investicije u obrazovanje imaju nešto manju pozitivnu korelaciju, srednjepozitivnu, ali svakako utiču na rast zaposlenosti. Ova dva indikatora imaju očekivanu korelaciju s brojem zaposlenih u regionu. Ipak, iznenađujuća je veza indikatora

Tabela 1 Korelacija BDP-a regiona sa osnovnim ekonomski indikatorima, prema Pirsonovom koeficijentu korelacije

\begin{tabular}{lcccc}
\hline & $\begin{array}{c}\text { Broj privrednih } \\
\text { društava u regionu }\end{array}$ & $\begin{array}{c}\text { Broj zaposlenih } \\
\text { u regionu }\end{array}$ & $\begin{array}{c}\text { Investicije u } \\
\text { osnovna sredstva }\end{array}$ & $\begin{array}{c}\text { Broj preduzetnika } \\
\text { u regionu }\end{array}$ \\
\cline { 2 - 5 } BDP regiona & 0,998 & 0,981 & 0,726 & 0,391 \\
\hline
\end{tabular}

Izvor: Autor, prema podacima Republičkog zavoda za statistiku Srbije (2012a) i Agencije za privredne registre (2012) 
Tabela 2 Korelacija zaposlenosti u regionima sa osnovnim indikatorima ljudskog kapitala, prema Pirsonovom koeficijentu korelacije

\begin{tabular}{lcccc}
\hline & $\begin{array}{c}\text { Stanovništvo radnog } \\
\text { uzrasta (16-64) }\end{array}$ & $\begin{array}{c}\text { Visoko obrazovno } \\
\text { stanovništvo }\end{array}$ & $\begin{array}{c}\text { Budžetski rashodi } \\
\text { u obrazovanje }\end{array}$ & $\begin{array}{c}\text { Investicije u } \\
\text { obrazovanje }\end{array}$ \\
\cline { 2 - 5 } $\begin{array}{l}\text { Broj zaposlenih } \\
\text { u regionu }\end{array}$ & $-0,177$ & $-0,197$ & 0,988 & 0,631 \\
\hline
\end{tabular}

Izvor: Autor, prema podacima Republičkog zavoda za statistiku Srbije (2011c, 2012b)

stanovništvo radnog uzrasta i visokoobrazovno stanovništvo sa indikatorom zaposlenosti. Ne samo da je zanemarljiva njihova korelaciona zavisnost, već je i negativna. Pirsonov koeficijent pokazuje da ovi indikatori u našim regionima gotovo nemaju nikakav uticaj na zaposlenost, ili zanemarljivo utiču na rast zaposlenosti (kada njihove vrednosti padaju).

Tabela 3 pokazuje da je korelaciona analiza indikatora poslovnog okruženja dala očekivane rezultate. Jaka pozitivna korelacija kvaliteta usluga države, atraktivnosti poslovnog ambijenta i raširenosti klastera ukazuje na veliki značaj ovih indikatora i njihovu savršenopozitivnu korelacionu zavisnost. $\mathrm{U}$ analizi indikatora raširenost klastera i atraktivnost poslovnog ambijenta, Pirsonov koeficijent je čak maksimalno pozitivan (1). Jaku pozitivnu zavisnost sa ovim indikatorima imaju i povezanost vazdušnog saobraćaja sa inostranstvom i nezavisnost sudstva, ali u malo manjoj meri. Sigurnost svojine i udeo sive ekonomije u poslovnim aktivnostima imaju srednje pozitivnu i slabu pozitivnu korelaciju sa indikatorima poslovnog okruženja, respektivno.

Inovacije imaju snažan uticaj na rast BDP-a regiona i na kreiranje i rast klastera (Tabela 4). Jaka pozitivna korelacija indikatora inovacija upravo potvrđuje ovu vezu. Gotovo svi indikatori inovacija su pokazali visoke pozitivne vrednosti Pirsonovog koeficijenta (preko 0,9), osim indikatora broj prijavljenih patenata i objavljeni naučno-istraživački radovi, koji imaju slabiju pozitivnu korelaciju. Poverenje ima snažnu pozitivnu korelaciju sa BDP-om. Visoko pozitivna vrednost koeficijenta govori da, što je veće poverenje u poslovne institucije, veći je i BDP.

Tabela 3 Korelacija osnovnih indikatora poslovnog okruženja, prema Pirsonovom koeficijentu korelacije

\begin{tabular}{|c|c|c|c|c|c|c|}
\hline \multirow[b]{2}{*}{$\begin{array}{l}\text { Kvalitet usluga } \\
\text { države }\end{array}$} & $\begin{array}{c}\text { Raširenost } \\
\text { klastera }\end{array}$ & $\begin{array}{c}\text { Povezanost } \\
\text { vazdušnog } \\
\text { saobraćaja sa } \\
\text { inostranstvom }\end{array}$ & $\begin{array}{l}\text { Udeo sive ekonomije } \\
\text { u poslovnim aktivnos- } \\
\text { tima }\end{array}$ & $\begin{array}{c}\text { Nezavisnost } \\
\text { sudstva }\end{array}$ & $\begin{array}{l}\text { Atraktivnost } \\
\text { poslovnog } \\
\text { ambijenta }\end{array}$ & $\begin{array}{l}\text { Sigurnost } \\
\text { svojine }\end{array}$ \\
\hline & 0,994 & 0,827 & 0,527 & 0,801 & 0,996 & 0,608 \\
\hline & $\begin{array}{l}\text { Raširenost } \\
\text { klastera }\end{array}$ & $\begin{array}{c}\text { Povezanost } \\
\text { vazdušnog } \\
\text { saobraćaja sa } \\
\text { inostranstvom }\end{array}$ & $\begin{array}{l}\text { Udeo sive ekonomije } \\
\text { u poslovnim aktivnos- } \\
\text { tima }\end{array}$ & $\begin{array}{c}\text { Nezavisnost } \\
\text { sudstva }\end{array}$ & $\begin{array}{l}\text { Sigurnost } \\
\text { svojine }\end{array}$ & $\begin{array}{l}\text { Kvalitet } \\
\text { usluga } \\
\text { države }\end{array}$ \\
\hline $\begin{array}{l}\text { Atraktivnost } \\
\text { poslovnog } \\
\text { ambijenta }\end{array}$ & 1,000 & 0,862 & 0,581 & 0,772 & 0,602 & 0,996 \\
\hline
\end{tabular}


Tabela 4 Korelacija osnovnih indikatora inovacija i neformalnih institucija, prema Pirsonovom koeficijentu korelacije

\begin{tabular}{lcccccc}
\hline & $\begin{array}{c}\text { Broj organizacija koje } \\
\text { se bave istraživanjem i } \\
\text { razvojem }\end{array}$ & $\begin{array}{c}\text { Izdaciza } \\
\text { istraživanje i } \\
\text { razvoj }\end{array}$ & $\begin{array}{c}\text { Investicije u } \\
\text { inovacije }\end{array}$ & $\begin{array}{c}\text { Broj prijavljenih } \\
\text { patenata }\end{array}$ & $\begin{array}{c}\text { Raširenost } \\
\text { klastera }\end{array}$ & $\begin{array}{c}\text { Poverenje } \\
\text { u poslovne } \\
\text { institucije }\end{array}$ \\
\cline { 2 - 7 } & 0,934 & 0,967 & 0,932 & 0,452 & 0,999 & 0,947 \\
\hline Broj zaposlenih u & $\begin{array}{c}\text { Izdaci za } \\
\text { istraživanje i } \\
\text { razvoj }\end{array}$ & $\begin{array}{c}\text { Ukupan broj } \\
\text { naučnih } \\
\text { radova }\end{array}$ & $\begin{array}{c}\text { Objav- } \\
\text { ljeni naučno- } \\
\text { istraživački } \\
\text { radovi }\end{array}$ & $\begin{array}{c}\text { Investicije u } \\
\text { inovacije }\end{array}$ & $\begin{array}{c}\text { Broj prijavlje- } \\
\text { nih patenata }\end{array}$ \\
\cline { 2 - 7 } & 0,961 & 0,957 & 0,947 & 0,580 & 0,918 & 0,482 \\
\hline
\end{tabular}

Izvor: Autor, prema podacima Republičkog zavoda za statistiku Srbije (2011a; 2011b; 2011c)

Turizam ima veoma slabu korelaciju sa indikatorima infrastrukture (Tabela 5). Male pozitivne vrednosti pokazuju zanemarljiv uticaj. Ukupne vode za snabdevanje imaju srednje-pozitivnu korelaciju sa turizmom, a korupcija slabu negativnu. Kod socijalnog faktora, najveća pozitivna korelacija je između indikatora investicije $\mathrm{u}$ vodosnabdevanje i upravljanje otpadnim vodama i količine opasnog otpada $u$ regionu. Sa ostalim indikatorima, količina opasnog otpada ima slabu ili srednju negativnu korelaciju, što je i očekivano.

\section{ZAKLJUČAK}

Konkurentnost je $\mathrm{u}$ tesnoj vezi sa porastom životnog standarda, većom mogućnošću zapošljavanja, kao i sposobnošću zemlje (privrede) da ispunjava svoje međunarodne obaveze. Značaj analize faktora i njihovih indikatora regionalne konkurentnosti i mogućnost da se primeni kompleksni program podizanja nivoa regionalne konkurentnosti je ogroman. Mnogi autori su kroz svoja istraživanja potvrdili ovo mišljenje (Porter, 1990, 1998; Storper, 2005; Cooke, 2004; Meyer-Stamer, 2008). Bez obzira na to da li konkurentnost posmatramo samo kao produktivnost (Krugman, 1990, 9) i/ili kroz rastući životni standard (Porter, 1992), konkurentnost se bazira na kumulativnom rezultatu ostvarenom na osnovu egzistencije različitih faktora koje region poseduje. Oni regioni, koji su se brže razvijali i koji raspolažu većim brojem različitih faktora imaju i bolju konkurentsku poziciju. Odnosno, veća iskorišćenost ili raspoloživost indikatora konkurentnosti pruža mogućnost da

Tabela 5 Korelacija osnovnih indikatora socijalnog faktora i turizma, prema Pirsonovom koeficijentu korelacije

\begin{tabular}{lccccc}
\hline & $\begin{array}{c}\text { Ukupne vode } \\
\text { za snabdevanje }\end{array}$ & $\begin{array}{c}\text { Investicije u vodosnab- } \\
\text { devanje i upravljanje } \\
\text { otpadnim vodama }\end{array}$ & Broj stanova & Broj turista & $\begin{array}{c}\text { Prosečna neto } \\
\text { zarada u regionu }\end{array}$ \\
\cline { 2 - 6 } $\begin{array}{l}\text { Količina opasnog } \\
\text { otpada u regionu }\end{array}$ & $-0,600$ & 0,975 & $-0,518$ & $-0,355$ & $-0,424$ \\
\hline \multirow{2}{*}{$\begin{array}{c}\text { Ukupne vode } \\
\text { za snabdevanje }\end{array}$} & Broj stanova & $\begin{array}{c}\text { Rasprostranjen- } \\
\text { ost korupcije }\end{array}$ & $\begin{array}{c}\text { Dužina savre- } \\
\text { menog kolovoza }\end{array}$ & Kvalitet železnice \\
\cline { 2 - 6 } & 0,676 & 0,098 & $-0,429$ & 0,234 & 0,254 \\
\hline
\end{tabular}

Izvor: Autor, prema podacima Republičkog zavoda za statistiku Srbije (2011c, 2012a) i sprovedenoj Anketi (Vuković, 2012) 
region gradi prednost nad faktorima regionalne konkurentnosti, koje upravo čine ovi indikatori.

Rad istražuje veoma aktuelnu i kompleksnu problematiku regionalne konkurentnosti, koja je višestruko interesantna $u$ širim razmerama, a posebno za našu literaturu i praksu. S obzirom na to da su pitanja konkurentnosti i regionalne politike veoma značajna za Republiku Srbiju, korelaciona analiza indikatora regionalne konkurentnosti pruža mogućnost da se utvrdi njihova veza i međuzavisnost. Ukoliko postoji značajna korelacija ovih indikatora, kreatori ekonomske politike mogu koristiti istraživanja za svrhu unapređenja regionalne konkurentnosti. Uticajem $\mathrm{i}$ investiranjem $\mathrm{u}$ određeni indikator, indirektno se poboljšavaju vrednosti drugih indikatora koji su visoko i pozitivno korelisani sa tim indikatorom. Osim toga, indikatori koji imaju niske vrednosti govore kreatorima ekonomske politike da upravo tu postoje „potencijalna uska grla konkurentnosti".

Ograničenje ovog rada se nalazi u grupaciji samo određenog broja indikatora, gde nisu analizirani i drugi indikatori regionalne konkurentnosti (poljoprivreda, geo-pozicija, industrija). Rezultati ne moraju biti pogrešni zbog ovog ograničenja, već ne prikazuju međuzavisnost svih indikatora. Ipak, postoje i indikatori kod kojih je apsurdno ispitivati korelacionu zavisnost, ali to ne znači da moraju biti izostavljeni iz merenja konkurentnosti regiona.

Može se zaključiti da najveći broj indikatora potvrđuje hipotezu po kojoj postoji korelaciona zavisnost između izabranih indikatora. Rast broja zaposlenih i privrednih društava u regionu ima skoro potpunu pozitivnu korelaciju sa rastom BDP-a (Pirsonov koeficijent korelacije je 0.99). Ovaj podatak govori da politika rasta zaposlenosti i preduzetništva ima veliki značaj za privredu ili region. Gotovo identično slaganje imaju i rashodi u obrazovanje, ako se uporede sa rastom zaposlenosti $u$ regionu. Ulaganjem države $u$ obrazovanje svojih građana, ne samo da se smanjuje nezaposlenost, već se indirektno utiče u budućnosti na rast BDP-a. Savršena korelacija (koeficijent 1) postoji u međuzavisnosti klastera, atraktivnosti poslovnog ambijenta i kvaliteta usluge države. Iako se govori o samo tri spomenuta indikatora, koji ukazuju na potpunu međuzavisnost, njihov razvoj i jačanje zahtevaju brojne reforme i dug proces unapređenja poslovnog ambijenta.

Analiza je ukazala i na veliki značaj investiranja u nauku i inovacije. Ovi indikatori pokazaju da porast investicija u naučno-istraživački rad i inovacije utiču u velikoj meri (koeficijent je 0,9 ) na rast $\mathrm{BDP}$-a regiona. $\mathrm{Na}$ kraju, rezultati istraživanja mogu pokrenuti teorijskometodološka i praktična pitanja koja se odnose na porast vrednosti pojedinih indikatora regionalne konkurentnosti, ali $\mathrm{i}$ na politiku konkurencije $\mathrm{u}$ Republici Srbiji.

\section{ZAHVALNICA}

Rad prezentira deo istraživanja na Projektu br. 47007/III, koji finansira Ministarstvo nauke Republike Srbije.

\section{REFERENCE}

Agencija za privredne registre. (2012). Registar privrednih subjekata. (Baza podataka ažurirana jul-avgust 2012).

Annoni, P., \& Kozovska, K. (2010). EU Regional Competitiveness Index 2010. European Commission, Joint Research Centre, Institute for the Protection and Security of the Citizen, Luxembourg. DOI 10.2788/88040

Boschma, R. A. (2004). The competitiveness of regions from an evolutionary perspective. Regional Studies, 38(9), 1001-1014. DOI: $10.1080 / 0034340042000292601$

Bristow, G. (2005). Everyone's a 'winner': problematising the discourse of regional competitiveness. Journal of Economic Geography, 5, 285-304. DOI: 10.1093/jeg/lbh063

Cho, D. S. (1994). The nine factor model. Reprinted in Cho, D. S., \& Moon, C. H. (2005). From Adam Smith to Michael Porter. Evolution of Competitiveness Theory. Asia-Pacific Business Series, 2, 135-160. DOI: 10.1142/9789814401661_0006

Cho, D. S., \& Moon, H. C. (2000). From Adam Smith to Michael Porter: Evolution of Competitiveness Theory. Korea: AsiaPacific Business Series. DOI: 10.1142/9789814401661_0003

Cooke, P. (2004). Competitiveness as cohesion: Social capital and the knowledge economy. In: Boddy, M. \& Parkinson, M. 
City Matters: Competitiveness, Cohesion and Urban Governance. 153-170. DOI:10.1332/policypress/9781861344458.003.0009

de Vet, J. M., Baker, P., Dalgleish, K., Pollock, R., \& Healy, A. (2004). The competitiveness of places and spaces: A Position Paper / Rotterdam / Leeds / Birmingham / Brussels.

Domanović, V. (2013). Efektivnost sistema merenja performansi u uslovima savremenog poslovnog okruženja. Ekonomski horizonti, 15(1), 31-44. DOI: 10.5937/ekonhor1301031D

European Commission. (1999). Sixth Periodic Report on the Social and Economic Situation of Regions in the EU. Brusel.

European Commission. (2001). Second Report on Economic and Social Cohesion. Brusel.

European Commission. (2003). In R. L. Martin (Ed.), A Study on the Factors of Regional Competitiveness. Draft final report for The European Commission Directorate-General Regional Policy. Bruselas: Cambridge Econometrics. Ecorys-NEI.

Freudenberg, M. (2003). Composite indicators of country performance: A critical assessment. STI working paper, 16, 2-34. DOI: $10.1787 / 405566708255$

Gardiner, G., Martin, R., \& Tyler, P. (2004). Competitiveness, productivity and economic growth across the European regions. Regional Studies 38(9), 1045-1068. DOI: $10.1080 / 0034340042000292638$

Giovannini, E., Nardo, M., Saisana, M., Saltelli, A., Tarantola, S., \& Hoffman, A. (2005). Constructing Composite Indicators: Methodology and User Guide. OECD Statistics Working Paper, STD/DOC OECD publishing. DOI: 10.1787/18152031

Huggins, R. (2003). Creating a UK Competitiveness Index: Regional and Local Benchmarking. Regional Studies, 37, 8996. DOI: $10.1080 / 0034340022000033420$

Huovari, J., Kangasharju, A., \& Alanen, A. (2001). Constructing an index for regional competitiveness. Pellervo Economic Research Institute Working Papers, Helsinki, 44. DOI: 10.1007/978-3-540-24823-1_7

IMD. (2000). The World Competitiveness Yearbook 2000. Lausanne.

IMD. (2004). The World Competitiveness Yearbook 2004. Lausanne.

Joksimović, Lj. (2008). Spiloveri stranih direktnih investicija i razvoj ljudskog kapitala: Tranzicione ekonomije i Srbija. U V. Babić, Lj. Maksimović (Ur.), Inostrani kapital kao faktor razvoja zemalja u tranziciji (str. 77-95). Kragujevac, Srbija: Ekonomski fakultet Univerziteta u Kragujevcu.

Kern, J. (2005). Je konkurencieschopnost regionu podmínkou jejich efektívniho rozvoje? In: New members - New Challenges for the European Regional Development Policy.
Kitson, M., Martin, R. \& Tyler, P. (2004). Regional Competitiveness: An Elusive yet Key Concept?, Regional Studies, 38(9), 991-999. DOI: 10.1080/0034340042000320816

Krugman, P. (1990). The Age of Diminished Expectations. Cambridge MA: MIT Press. DOI: 10.1177/027046769201200251

Krugman, P. (1994). Competitiveness: A Dangerous Obsession. Foreign Affairs, 73(2), 28-44. http://www.jstor.org/discover/10 .2307/20045917?uid=3738928\&uid=2134\&uid=2\&uid=70\&uid $=4 \& \operatorname{sid}=21103026428461$

Krugman, P. (1996). Making sense of the competitiveness debate. Oxford Review of Economic Policy, 12(3), 17-25. DOI: 10.1093/oxrep/12.3.17

Leković, V. (2012). Poverenje kao institucionalni faktor ekonomske uspešnosti. Ekonomski horizonti, 14(2), 65-75. DOI: 10.5937/ekonhor1202063L

Lengyel, I. (2004). The pyramid model: enhancing regional competitiveness in Hungary. Acta Oeconomica, 54(3), 323342. DOI: 10.1556/AOecon.54.2004.3.3

Martin, R. (2005). A Study on the Factors of Regional Competitiveness. A draft final report for the European Commission Directorate-General Regional Policy. European Commission.

Martin, R., Kitson, M., \& Tyler, P. (2006). Regional Competitiveness. London, UK: Routledge. DOI: 10.1177/00420980070440110905

Meyer-Stamer, J. (2008). Systematic Competitiveness and Local Economic Development. In Shamin Bodhanya (Ed.), Large Scale Systemic Change: Theories, Modelling and Practices.

Organisation for Economic Cooperation and Development (OECD). (1997). Regional Competitiveness and Skills. Paris, France: OECD.

Powell, T. C. (2001). Competitive advantage: logical and philosophical considerations. Strategic Management Journal, 22(9), 875-888. DOI: 10.1002/smj.173

Porter, M. (1990). The Competitive Advantage of Nations. London, UK: MacMillan Press. DOI: 10.1002/cir.3880010112

Porter, M. (1992). Competitive Advantage: Creating and Sustaining Superior Performance. Issue 10. PA Consulting Group, London. DOI: 10.1590/s0034-75901985000200009

Porter, M. (1998). On Competition. Boston, USA: Harvard Business School.

Reiljan, J., Hinrikus, M., \& Ivanov, A. (2000). Key issues in defining and analysing the competitiveness of a country. Working Paper Series. University of Tartu, Faculty of Business and Administration, 1, 59 DOI: 10.2139/ssrn.418540 
Republički zavod za statistiku. (2011a). Statistički godišnjak Republike Srbije. Beograd.

Republički zavod za statistiku. (2011b). Naučnoistraživačka delatnost u Republici Srbiji, 2010. Beograd.

Republički zavod za statistiku. (2011c). Opštine i regioni u Republici Srbiji. Beograd.

Republički zavod za statistiku. (2012a). Statistički kalendar Republike Srbije. Beograd.

Republički zavod za statistiku. (2012b). Anketa o radnoj snazi, 2011. Beograd.

Rugman, A. M., Moon, C. H., \& Verbeke, A. (1998). The Generalized Double Diamond Model. Reprinted in Cho, D. S., \& Moon, C. H. (2005). From Adam Smith to Michael Porter. Evolution of Competitiveness Theory. Asia-Pacific Business Series, 2, 111-133. DOI: 10.1142/9789814401661_0005

Ručinska, S., \& Ručinsky, R. (2007). Factors of regional competitiveness. 2nd Central European Conference in Regional Science - CERS, 2007. Technical University of Košice, Faculty of Economics.

Schwab, K., \& Porter, M. E. (2007). The Global Competitiveness Report 2007-2008. Geneva, Switzerland: World Economic Forum.

Saisana, M., Tarantola, S., Schulze, N., Cherchye, L., Moesen, W., \& Van Puyenbroeck, T. (2005). Knowledge Economy Indicators. State-of-the-Art Report on Composite Indicators for the Knowledge-based Economy. Workpackage 5.
Snieška, V., \& Bruneckienė, J. (2009). Measurement of Lithuanian regions by regional competitiveness index. Engineering economics, 1(61).

Storper, M. (2005). Society, Community and Economic Development. Studies in Comparative International Development, 39(4), 30-57. DOI: 10.1007/BF02686164

Vuković, D., \& Wei, L. (2010). Regional competitiveness: the case of western China. Journal of Geographical institute „Jovan Cvijić" of Serbian academy of sciences and arts, 60(1), 107-124. DOI: 911.2/.3(51)

Vuković, D., Jovanović, A., \& Đukić,, M. (2012). Defining competitiveness through the theories of new economic geography and regional economy. Journal of Geographical institute "Jovan Cvijic" of Serbian academy of sciences and arts, 62(3), 49-64. DOI: 10.2298/IJGI1203049V

Vuković, D. (2012). Anketa, sprovedena za potrebe Doktorske disertacije.

Vuković, D. (2013). Model regionalne konkurentnosti: Teorijsko-metodološka analiza $i$ mogućnosti primene u Srbiji. Nepublikovana doktorska disertacija, Ekonomski fakultet Univerziteta u Kragujevcu, Srbija.

Wignaraja, G., Lezama, M., \& Joiner, D. (2004). Small States in Transition: From Vulnerability to Competitiveness. United Kingdom: Commonwealth Secretariat. DOI: 10.1177/0047287510368139

Ward Thompson, C. (2005). Who benefits from landscape architecture? In S. Harvey, \& K. Fieldhouse (Eds.), The Cultured Landscape: Designing the environment in the 21st century (pp. 95-124). Abingdon and New York, NY: Routledge.

Primljeno 9. novembra 2013, nakon revizije, prihvaćeno za publikovanje 17. decembra 2013.

Darko B. Vuković je naučni saradnik Geografskog instituta "Jovan Cvijić" Srpske akademije nauka i umetnosti (SANU), u oblasti regionalne ekonomije i ekonomske geografije. Doktorirao je na Ekonomskom fakultetu Univerziteta u Kragujevcu. Ključne oblasti naučnog interesovanja i rada su regionalna ekonomija, makroekonomija i međunarodne finansije. 


\section{DODATAK}

Tabela 6 Varijable indikatora za ekonomski faktor

\begin{tabular}{lccccc}
\hline Regioni & $\begin{array}{c}\text { Bruto društveni proiz- } \\
\text { vod (u mil. RSD)* }\end{array}$ & $\begin{array}{c}\text { Broj privrednih } \\
\text { društava** }\end{array}$ & $\begin{array}{c}\text { Broj } \\
\text { preduzetnika** }\end{array}$ & $\begin{array}{c}\text { Broj } \\
\text { zaposlenih* }\end{array}$ & $\begin{array}{c}\text { Investicije u } \\
\text { osnovna sredstva* }\end{array}$ \\
\hline Srbija & 2986614 & 103548 & 20500 & 1746138 & 425400001 \\
$\begin{array}{l}\text { Beograd } \\
\text { Južna i Istočna }\end{array}$ & 1193867 & 45724 & 54239 & 576905 & 210458922 \\
$\begin{array}{l}\text { Srbija } \\
\text { Šumadija i Zapadna } \\
\text { Srbija }\end{array}$ & 433502 & 11600 & 40371 & 305543 & 100024608 \\
Vojvodina & 583366 & 15993 & 60595 & 403104 & 63607782 \\
\hline
\end{tabular}

Izvor: * Republički zavod za statistiku Srbije, 2012a; **APR (Registar privrednih subjekata, podaci za avgust 2012.)

Tabela 7 Varijable indikatora za faktor ljudskih resursa

\begin{tabular}{lcccc}
\hline Regioni & $\begin{array}{c}\text { Stanovništvo radnog } \\
\text { uzrasta (15-64) }\end{array}$ & $\begin{array}{c}\text { Visoko-obrazova- } \\
\text { no stanovništvo } \\
(\%)\end{array}$ & $\begin{array}{c}\text { Budžetski rashodi u } \\
\text { obrazovanje (u RSD) }\end{array}$ & $\begin{array}{c}\text { Investicije u obrazovanje } \\
\text { (u 000 RSD) }\end{array}$ \\
\hline Srbija & 4775996 & 9,5 & 140002218 & 3901604 \\
Beograd & 1047347 & 7 & 41860479 & 1063191 \\
$\begin{array}{l}\text { Južna i Istočna } \\
\text { Srbija }\end{array}$ & 1088708 & 7 & 26040688 & 859503 \\
Šumadija i Zapadna & 1334805 & 8,2 & 29853708 & 777722 \\
Srbija & 1305135 & 7 & 35750195 & 1170640 \\
Vojvodina & & & & 8 \\
\hline
\end{tabular}

Izvor: Republički zavod za statistiku Srbije (2011c, 2012b) 
Tabela 8 Varijable indikatora za faktor inovacija

\begin{tabular}{lccc}
\hline Regioni & $\begin{array}{c}\text { Broj organizacija koje se bave } \\
\text { istraživanjem i razvojem* }\end{array}$ & $\begin{array}{c}\text { Broj zaposlenih u } \\
\text { istraživanju i razvoju* }\end{array}$ & $\begin{array}{c}\text { Izdaci za istraživanje i } \\
\text { razvoj (u o0o dinara)* }\end{array}$ \\
\hline Srbija & 271 & 20067 & 24944966 \\
Beograd & 160 & 11384 & 18109050 \\
Južna i Istočna Srbija & 34 & 2115 & 998815 \\
Šumadija i Zapadna & 32 & 1332 & 1137281 \\
Srbija & 45 & 5236 & 4699820 \\
Vojvodina & n/a & n/a & n/a \\
Kosovo i Metohija & Ukupan broj naučnih radova* & Investicije u inovacije & Broj prijavljenih \\
(u o0o dinara)*** & patenata** \\
\hline Regioni & 7034 & 26543143 & 93 \\
\hline Srbija & 5044 & 21089554 & 26 \\
Beograd & 402 & 1039094 & 2 \\
Južna i Istočna Srbija & 357 & 1767264 & 5 \\
Šumadija i Zapadna & 1231 & 2647231 & 60 \\
Srbija & & & \\
Vojvodina & & & \\
\hline
\end{tabular}

Izvor: Republički zavod za statistiku Srbije ${ }^{*}$ 2011a; ${ }^{* *} 2011 b ;{ }^{* * *}$ 2011c)

Tabela 9 Varijable indikatora za socijalni faktor

\begin{tabular}{lcc}
\hline Regioni & Broj stanova & $\begin{array}{c}\text { Rasprostranje- } \\
\text { nost korupcije } \\
\text { (u \%) }\end{array}$ \\
\hline Srbija & 3243587 & 9,3 \\
Beograd & 739630 & 10,9 \\
Južna i Istočna & 748731 & 9,9 \\
Srbija & 902997 & 6,7 \\
Šumadija i Zapadna & 852229 & 9,9 \\
Srbija & & \\
Vojvodina & &
\end{tabular}

Izvor: Republički zavod za statistiku Srbije (2012a)
Tabela 10 Varijable indikatora za faktor Kultura i turizam

\begin{tabular}{lcc}
\hline Regioni & Broj turista & $\begin{array}{c}\text { Ukupno } \\
\text { noćenje turista }\end{array}$ \\
\hline Srbija & 2000597 & 6413515 \\
Beograd & 618454 & 1319629 \\
Južna i Istočna Srbija & 392044 & 2649943 \\
Šumadija i Zapadna & 663208 & 2516236 \\
Srbija & 281842 & 767304 \\
Vojvodina & & \\
\hline
\end{tabular}

Izvor: Republički zavod za statistiku Srbije (2011c - podaci preuzeti iz Ministarstva finansija - Uprave za trezor) 
Tabela 11 Indikatori percepcije, prema mišljenju eksperata

\begin{tabular}{lcccc}
\hline Regioni & $\begin{array}{c}\text { Raširenost } \\
\text { klastera }\end{array}$ & $\begin{array}{c}\text { Povezanost vazdušnog sao- } \\
\text { braćaja sa inostranstvom }\end{array}$ & $\begin{array}{c}\text { Kvalitet } \\
\text { železnice }\end{array}$ & $\begin{array}{c}\text { Kvalitet elektro-energetske } \\
\text { infrastrukture }\end{array}$ \\
\hline Srbija & 100 & 100 & 100 & 100 \\
Beograd & 124,19 & 218,63 & 122,38 & 143,09 \\
Južna i Istočna Srbija & 75,00 & 61,75 & 68,29 & 72,00 \\
Šumadija i Zapadna & 85,43 & 48,06 & 74,78 & 85,93 \\
Srbija & 98,83 & 49,45 & 91,42 & 105,01 \\
Vojvodina & & &
\end{tabular}

Izvor: Vuković, 2012

Tabela 12 Indikatori percepcije, prema mišljenju eksperata

\begin{tabular}{lcccccc}
\hline Regioni & $\begin{array}{c}\text { Poverenje } \\
\text { u poslovne } \\
\text { institucije }\end{array}$ & $\begin{array}{c}\text { Sigurnost } \\
\text { svojine }\end{array}$ & $\begin{array}{c}\text { Udeo sive eko- } \\
\text { nomije u poslovnim } \\
\text { aktivnostima }\end{array}$ & $\begin{array}{c}\text { Nezavisnost } \\
\text { sudstva }\end{array}$ & $\begin{array}{c}\text { Atraktivnost } \\
\text { poslovnog } \\
\text { ambijenta }\end{array}$ & $\begin{array}{c}\text { Kvalitet } \\
\text { usluga } \\
\text { države }\end{array}$ \\
\hline Srbija & 100 & 100 & 100 & 100 & 100 & 100 \\
Beograd & 100,31 & 91,79368 & 103,44 & 83,81211 & 193,71 & 121,6984 \\
Južna i Istočna Srbija & 76,02 & 88,39 & 93,20 & 74,39 & 64,77 & 72,73 \\
Šumadija i Zapadna & 85,94 & 88,95 & 86,72 & 79,33 & 94,20 & 88,14 \\
Srbija & 93,49 & 94,36 & 83,15 & 85,62 & 126,14 & 97,97 \\
Vojvodina & & & & & & \\
\hline
\end{tabular}

Izvor: Vuković, 2012 


\title{
CORRELATION ANALYSIS OF INDICATORS OF REGIONAL COMPETITIVENESS: THE CASE OF THE REPUBLIC OF SERBIA
}

\author{
Darko B. Vukovic \\ Geographical Institute „Jovan Cvijić" of the Serbian Academy of Sciences and Arts
}

The identification and analysis of the indicators of regional competitiveness is the most important phase of the process of measuring competitiveness. However, prior to the measurements, it is necessary to determine whether there is a high correlation between the selected indicators or not. The aim of this paper is to determine whether there is a high correlation between the most important indicators of regional competitiveness or not. The subject of this paper are the indicators of competitiveness in Serbia's regions, whose values are measured in the 2011-2013 period. For the indicators unrelated to each other or those having no logical mutual influence, no correlation was revealed. On the basis of these results, it turns out that there is a high correlation between the GDP of the region, the number of companies in the region, the number of employees, the extent of the cluster, investments in innovation and confidence in business institutions. The Pearson correlation coefficient statistical method has been used in the estimation. These data, whose measure cannot be achieved through quantitative measurement, have been obtained in the survey.

Keywords: regional competitiveness, indicators of regional competitiveness, correlation analysis of the indicators of regional competitiveness

JEL Classification: R10, R58, 018 